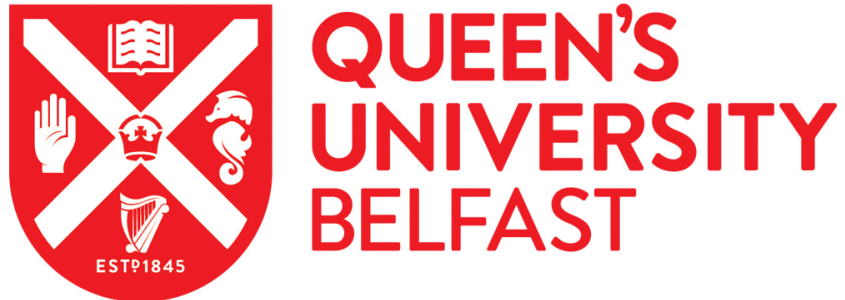

\section{Guidelines for mix proportioning of fly ash/GGBS based alkali activated concretes}

Rafeet, A., Vinai, R., Soutsos, M., \& Sha, W. (2017). Guidelines for mix proportioning of fly ash/GGBS based alkali activated concretes. Construction and Building Materials, 147, 130-142.

https://doi.org/10.1016/j.conbuildmat.2017.04.036

\section{Published in:}

Construction and Building Materials

\section{Document Version:}

Peer reviewed version

\section{Queen's University Belfast - Research Portal:}

Link to publication record in Queen's University Belfast Research Portal

\section{Publisher rights}

Copyright 2017 Elsevier.

This manuscript is distributed under a Creative Commons Attribution-NonCommercial-NoDerivs License

(https://creativecommons.org/licenses/by-nc-nd/4.0/), which permits distribution and reproduction for non-commercial purposes, provided the author and source are cited.

\section{General rights}

Copyright for the publications made accessible via the Queen's University Belfast Research Portal is retained by the author(s) and / or other copyright owners and it is a condition of accessing these publications that users recognise and abide by the legal requirements associated with these rights.

Take down policy

The Research Portal is Queen's institutional repository that provides access to Queen's research output. Every effort has been made to ensure that content in the Research Portal does not infringe any person's rights, or applicable UK laws. If you discover content in the Research Portal that you believe breaches copyright or violates any law, please contact openaccess@qub.ac.uk. 


\title{
Guidelines for mix proportioning of fly ash/GGBS based alkali activated concretes
}

\author{
Ali Rafeet, Raffaele Vinai*, Marios Soutsos and Wei Sha \\ School of Natural and Built Environment, Queen's University Belfast, BT9 5AG United Kingdom \\ *corresponding author: r.vinai@qub.ac.uk, tel. +44 (0)28 90974032
}

\begin{abstract}
The effects of paste volume, water content and precursor blend on consistency, setting time and compressive strength of alkali activated concrete (AAC) produced with fly ash (FA) and ground granulated blast furnace slag (GGBS) have been investigated with the aim of developing a suitable mix design procedure. Paste volumes in the range $30 \%$ - 33\% were found not to influence the compressive strength but did influence the consistency of the mixes. The water-to-solid ratio was found to influence compressive strength and setting time. Increasing GGBS content in the binder blend resulted in an increase of the compressive strength, but higher GGBS content caused also early setting which may be undesirable. A mix design procedure has been developed and has been used to determine the constituent mix proportions for three classes of concretes, i.e. (a) a ready-mix concrete with nominal strength $35 \mathrm{MPa}$, (b) a typical structural concrete with nominal strength $50 \mathrm{MPa}$, and (c) a high strength concrete for precast applications with nominal strength $70 \mathrm{MPa}$. Cost analysis was carried out to compare the AAC with Portland cement concretes with similar properties. Normal strength Portland cement concrete (PC), as typically used in ready mix industry has been shown to be less expensive than AAC. However, alkali activated concrete can be competitively priced for high strength concretes. An empirical step-by-step procedure is presented for selecting trial mix proportions for concretes with a range of consistency values, setting times and cube compressive strengths.
\end{abstract}

Keywords: selection of mix proportions, alkali activated binders/concretes, fly ash, ground granulated blast furnace slag

\section{Introduction}

Early investigations on alkali activated binder $(\mathrm{AAB})$ date back to the beginning of the $20^{\text {th }}$ century thanks to pioneering work by Kühl in Germany which was on vitreous slags activated with alkali materials [1]. However, it was only in the last decade that they gained international attention as alternative to Portland cement (PC) based binders, mainly due to the potential reduction of associated $\mathrm{CO}_{2}$ emissions and for their inherent 
properties such as high strength, good resistance to chemical degradation, thermal stability and fire resistance, among others [2].

An extensive literature can be found on AAB. Detailed and up-to-date reviews are available [1]. While the majority of the studies have focused on the reaction mechanism and microstructural characterisation of $\mathrm{AAB}$, relatively few investigations have been carried out with the aim of developing guidelines for concrete mix design proportioning [5 - 13]. Despite this, commercial binders have been marketed in Europe, USA, Australia and India, sometimes labelled as 'geopolymer concrete', and patents have been filed [3, 4].

Available studies for mix proportioning on geopolymer or alkali activated concretes (AAC) have mainly focused on neat fly ash (FA) as the precursor [5 - 13]. Factors such as dosage of alkali solutions, water content, elevated curing temperatures $\left(60\right.$ to $\left.100{ }^{\circ} \mathrm{C}\right)$ and curing time are considered to be the important factors influencing the properties of fly ash-based AAC. Studies reported that reinforced concrete structural elements such as full scale beams and columns showed mechanical properties not dissimilar to those of Portland cementbased concrete $[12,14]$. Recently, a mix design procedure has been proposed for fly ash based geopolymer concretes applicable (1) to when they are cured at 60 or $80{ }^{\circ} \mathrm{C}$, and (2) only to two $\mathrm{NaOH}$ solution concentrations [15]. The parameters considered in the design procedure for obtaining required compressive strength and workability were water to geopolymer solid ratio, alkali solution/fly ash and alkali solution/water ratios. Fly ash based geopolymer concrete requires both high chemical dosages and elevated curing temperature to achieve suitable mechanical properties, which may lead to limited applications as a result of higher production costs. Higher chemical activator quantities also increase the embodied energy of AAC making it less favourable as a way for reducing the environmental impact of construction.

Ground granulated blast furnace slag (GGBS) is also used as a precursor on its own or blended with fly ash to produce $\mathrm{AAC}$ cured at room temperature with high mechanical performance whilst requiring relatively low activator dosage. However, this option has also some practical challenges to overcome, such as fast setting of high calcium alkali activated systems [16]. Chemical admixtures used as retarders for Portland cement have not proved to be compatible for AAB. Detrimental effects on compressive strength have often been observed with some of them [17]. Till now no new chemical admixtures have been identified that overcome this problem. Mechanical strength for slag-based AAC was found to be higher than that of Portland cement-based concrete produced with similar binder content, water content, and curing temperature [18]. It was also observed that the strength development of slag-based AAC was less affected by the binder content than that of PC concrete. Slagbased AAC also had lower water absorption and lower total porosity than PC concrete. However, these properties decrease with increasing the binder content [18]. Hung and Chang [19] reported that the effect of 
liquid-to-binder ratio was less pronounced in slag-based AAC than in PC concrete. It was also observed that variables such as sand/aggregate and paste/aggregate ratios affected the fresh and hardened properties of slagbased AAC in a similar way to conventional PC concrete. The 28-day compressive strength was found to reach $80 \%$ of the 90 -day strength, which is not much dissimilar to PC concrete, thus the 28-day strength can be used for designing slag-based AAC in a similar way to PC concretes.

Some studies have investigated the production of geopolymer concrete with blends of fly ash/GGBS [16, 2022]. The main observations from these studies were:

- Consistency decreased with increasing the GGBS content up to $30 \%$ by weight of the total binder when the binder was kept constant at $400 \mathrm{~kg} / \mathrm{m}^{3}$. The decrease of the consistency was attributed to the accelerated reaction of the calcium species and the angular shape of GGBS particles compared to the spherical shape of the fly ash $[16,20]$.

- Consistency decreased with the reduction of the activator to binder ratio but it improved with the addition of extra water, which however led to reductions in strength. The addition of slag was found to accelerate the setting at ambient temperature. Maximum slag content of $10 \%$ was recommended for achieving concrete with strength and setting times similar to PC concretes [16].

- Compressive strength increased with increasing slag content in the investigated range of up to $30 \%$ [21]. Setting time was also reported to decrease as the amount of slag and the concentration of the $\mathrm{NaOH}$ solution increased. The "optimum" slag content in an alkali-activated fly ash/slag mixture was proposed to be 15$20 \%$ of total binder by weight considering setting time and workability of concrete.

The control of fresh and hardened properties of fly ash/GGBS concrete through a suitable mix design procedure is still desired. Reaction processes and products are completely different from those of Portland cement, and the empirical procedures usually adopted for the mix design of PC concretes cannot be used for AAC. The objectives of this study were:

- To assess the effects of different water/solids ratio, paste volume, fly ash/GGBS blends on the setting time and strength development of AAC.

- To quantify the effect of water content on the binder setting behaviour.

- To determine guidelines for mix proportioning of AAC.

- To compare the cost of AAC and PC concretes with similar compressive strengths and consistency. The effect of aggregate shape, texture and grading, as well as the effect of other activators (potassium-based solutions, carbonates etc.) and admixtures were not part of this study. 


\section{Materials and experimental procedures}

\subsection{Materials}

Power Minerals Ltd supplied the fly ash from their Drax Power Station in the UK. The Rietveld method was used for assessing the amorphous content (internal standard of $\mathrm{Al}_{2} \mathrm{O}_{3}, 20 \%$ in weight, was used). Quartz (4.6\%) and mullite $(8.1 \%)$ were the main crystalline phases identified, whilst hematite $(0.5 \%)$ and magnetite $(0.8 \%)$ were also detected. The amorphous content was estimated at $86 \%$. The measured volumetric mass density of the particles was $2.42 \mathrm{~g} / \mathrm{cm}^{3}$. Particle size analysis was carried out with laser diffraction and the obtained mean particle size $\left(\mathrm{d}_{50}\right)$ was $17 \mu \mathrm{m}$.

GGBS was supplied by Civil and Marine Ltd - Hanson Company, West Thurrock, Essex, UK. XRD allowed the identification of akermanite and gehlenite in crystalline state, whereas the amorphous content was found to be higher than $95 \%$. The volumetric mass density of the particles was $2.92 \mathrm{~g} / \mathrm{cm}^{3}$ and the $\mathrm{d}_{50}$ was $15 \mu \mathrm{m}$.

X-ray diffraction (XRD), with the use of a Philips X'Pert MPD diffractometer (which uses Cu-K- $\alpha$ radiation) determined the mineralogical composition.

$\mathrm{X}$-ray fluorescence (XRF) was used to determine the chemical composition of the precursor materials. Main oxides are shown in Table 1.

Table 1. Main oxides determined by XRF analysis on precursor materials.

\begin{tabular}{cccccccccccccc}
\hline Oxide & $\mathbf{N a}_{2} \mathbf{O}$ & $\mathbf{M g O}$ & $\mathbf{A l}_{2} \mathbf{O}_{3}$ & $\mathbf{S i O}_{2}$ & $\mathbf{P}_{2} \mathbf{O}_{5}$ & $\mathbf{S O}_{3}$ & $\mathbf{K}_{2} \mathbf{O}$ & $\mathbf{C a O}$ & $\mathbf{T i O}_{2}$ & $\mathbf{M n O}$ & $\mathbf{F e}_{2} \mathbf{O}_{3}$ & ${ }^{\mathbf{B a O}}$ & $\mathbf{L O I}$ \\
\hline FA & 0.89 & 1.33 & 22.52 & 46.78 & 0.17 & 0.90 & 4.09 & 2.24 & 1.05 & 0.05 & 9.15 & 0.10 & 3.57 \\
GGBS & 1.05 & 6.94 & 11.23 & 29.38 & 0.00 & 1.76 & 0.93 & 43.72 & 0.67 & 0.51 & 0.36 & 0.12 & 2.40 \\
\hline
\end{tabular}

Chemical activators were: $\mathrm{NaOH}$ in powder form of $99 \%$ purity and sodium silicate as a solution with $\mathrm{SiO}_{2}$ to $\mathrm{Na}_{2} \mathrm{O}$ molar ratio of 2.055 . The commercial sodium silicate solution, produced by Fisher Scientific, had the following composition: $12.8 \%$ of $\mathrm{Na}_{2} \mathrm{O}, 25.5 \%$ of $\mathrm{SiO}_{2}, 61.7 \%$ of water, by weight. $\mathrm{NaOH}$ solution with concentration $30 \%$ by weight (Molarity $\approx 10 \mathrm{M}$ ) was prepared by dissolving $\mathrm{NaOH}$ in tap water. Chemical activators were added in the mixes according to the alkali dosage $(\mathrm{M}+)$ and the alkali modulus (AM).

$\mathrm{M}+$ is the mass ratio of sodium oxide $\left(\mathrm{Na}_{2} \mathrm{O}\right)$ in the activating solution (i.e. $\mathrm{Na}_{2} \mathrm{O}$ from $\mathrm{NaOH}$ solution $+\mathrm{Na}_{2} \mathrm{O}$ from sodium silicate solution) to the binder dry mass:

$M+=\frac{\mathrm{Na}_{2} \mathrm{O}}{f l y a s h+g g b s}$

Alkali modulus (AM) is the mass ratio $\mathrm{Na}_{2} \mathrm{O} / \mathrm{SiO}_{2}$ in the alkali solutions.

The following dosages were chosen for this work: $\mathrm{M}+=7.5 \%, \mathrm{AM}=1.25$. These values ensured satisfactory strength and setting time, whilst offering the possibility for reduced production costs and environmental 
impacts. This was based on a preliminary study of the effect of chemical dosage on the reaction of fly ash-based systems (100\% fly ash) and GGBS-rich systems (30\% fly ash and 70\% GGBS) carried out on mortars [23]. The strength was found to increase with increasing AM, reaching an optimum before decreasing. The drop in strength after the optimum may be due to the reduced amount of available silica required for the geopolymer reactions to develop. Optimum values of $\mathrm{AM}$ were found to be in the range $0.95-1.25$. An increase in $\mathrm{M}+$ resulted in higher compressive strengths, although the increase was smaller for $\mathrm{M}+$ higher than $9.5 \%$ and $7.5 \%$ for neat fly ash systems and rich GGBS systems respectively. Higher dosages, beside cost and environmental implications, were found to trigger fast setting, observed also in fly ash-based AAC for very high dosages (M+ $\geq 12.5 \%)$.

The water/solids (w/s) ratio is the mass ratio of the water in the system (i.e. water in the activating solutions + added water) to the solids (i.e. precursors + alkali solids). Aggregates used were natural sand (0/4 mm) and quarried basalt of two sizes: $4 / 10 \mathrm{~mm}$ and $10 / 20 \mathrm{~mm}$. The aggregate proportions were the following (by volume): $40 \%$ of total aggregate was sand whilst the coarse aggregate size of $4 / 10 \mathrm{~mm}$ was $40 \%$ of total coarse aggregate volume. Bulk density of the aggregate blend was assessed by filling a 7 litres vessel and then measuring its weight in loose and vibrated state. Obtained values were 1797 and $2126 \mathrm{~kg} / \mathrm{m}^{3}$ for loose and compacted samples respectively. Void contents in these two conditions were determined according to the aggregate grain densities and obtained values were $34 \%$ and $22 \%$ in loose and compacted state respectively. Aggregates were oven-dried. They were subsequently wetted to saturated-surface-dry condition by adding the required mass of water. This was calculated based on their one-hour water absorption. The water absorbed by the aggregate was not included in the water/solid ratio.

Four blends of FA/GGBS were investigated: 100/0, 80/20, 60/40 and 30/70, where numbers refer to the mass percentage of fly ash and GGBS in each ratio. Binder content is defined as the mass of the aluminosilicate materials (FA + GGBS) per unit volume of concrete (cubic metre), whilst the paste volume is defined as the volume of the aluminosilicate materials + alkali solutions + tap water in a unit volume of concrete (cubic metre). Values of the percentage paste volume refer to quantities required for a cubic metre of concrete. The mix proportions for all concretes investigated are shown in Tables 2 to 5. 
Table 2. Mix proportions for 100/0 fly ash/GGBS mixes (100/0).

\begin{tabular}{|c|c|c|c|c|c|c|c|c|c|c|c|c|}
\hline $\begin{array}{c}\text { Mix } \\
\text { label }\end{array}$ & $\begin{array}{l}\text { Fly ash } \\
\left(\mathrm{kg} / \mathrm{m}^{3}\right)\end{array}$ & $\begin{array}{c}\text { GGBS } \\
\left(\mathrm{kg} / \mathrm{m}^{3}\right)\end{array}$ & $\begin{array}{c}\text { SS sol. } \\
\left(\mathrm{kg} / \mathrm{m}^{3}\right)\end{array}$ & $\begin{array}{c}\mathrm{NaOH} \\
\text { sol. } \\
\left(\mathrm{kg} / \mathrm{m}^{3}\right)\end{array}$ & $\begin{array}{c}\text { Free } \\
\text { Water } \\
\left(\mathbf{k g} / \mathbf{m}^{3}\right)\end{array}$ & $\begin{array}{c}\text { Sand 0/4 } \\
\left(\mathrm{kg} / \mathrm{m}^{3}\right)\end{array}$ & $\begin{array}{c}\text { Gravel } \\
4 / 10 \\
\left(\mathrm{~kg} / \mathrm{m}^{3}\right)\end{array}$ & $\begin{array}{c}\text { Gravel } \\
10 / 20 \\
\left(\mathrm{~kg} / \mathrm{m}^{3}\right)\end{array}$ & $\begin{array}{c}\text { Theo. } \\
\text { density } \\
\left(\mathrm{kg} / \mathrm{m}^{\mathbf{3}}\right)\end{array}$ & $\begin{array}{c}\text { Binder } \\
\text { content } \\
\left(\mathrm{kg} / \mathrm{m}^{3}\right)\end{array}$ & $\begin{array}{c}\text { Paste } \\
(\text { vol.\%) }\end{array}$ & $\begin{array}{c}\text { w/s } \\
\text { ratio }\end{array}$ \\
\hline $10 \mathrm{Cl}$ & 391 & 0 & 92 & 75 & 46 & 721 & 450 & 661 & 2436 & 391 & $33 \%$ & 0.35 \\
\hline $10 \mathrm{C} 2$ & 380 & 0 & 89 & 73 & 54 & 721 & 450 & 661 & 2428 & 380 & $33 \%$ & 0.37 \\
\hline $10 \mathrm{C3}$ & 371 & 0 & 87 & 72 & 61 & 721 & 450 & 661 & 2423 & 371 & $33 \%$ & 0.39 \\
\hline $10 \mathrm{C} 4$ & 367 & 0 & 86 & 71 & 44 & 742 & 464 & 681 & 2455 & 367 & $31 \%$ & 0.35 \\
\hline $10 C 5$ & 357 & 0 & 84 & 69 & 50 & 742 & 464 & 681 & 2447 & 357 & $31 \%$ & 0.37 \\
\hline $10 \mathrm{C6}$ & 348 & 0 & 82 & 67 & 57 & 742 & 464 & 681 & 2441 & 348 & $31 \%$ & 0.39 \\
\hline $10 C 7$ & 355 & 0 & 84 & 69 & 42 & 753 & 470 & 690 & 2463 & 355 & $30 \%$ & 0.35 \\
\hline $10 \mathrm{C8}$ & 346 & 0 & 81 & 67 & 49 & 753 & 470 & 690 & 2456 & 346 & $30 \%$ & 0.37 \\
\hline 10C9 & 337 & 0 & 79 & 65 & 55 & 753 & 470 & 690 & 2449 & 337 & $30 \%$ & 0.39 \\
\hline
\end{tabular}

Table 3. Mix proportions for $80 / 20$ fly ash/GGBS mixes (80/20).

\begin{tabular}{|c|c|c|c|c|c|c|c|c|c|c|c|c|}
\hline $\begin{array}{c}\text { Mix } \\
\text { label }\end{array}$ & $\begin{array}{r}\text { Fly ash } \\
\left(\mathrm{kg} / \mathrm{m}^{3}\right)\end{array}$ & $\begin{array}{c}\text { GGBS } \\
\left(\mathbf{k g} / \mathbf{m}^{3}\right)\end{array}$ & $\begin{array}{c}\text { SS sol. } \\
\left(\mathrm{kg} / \mathrm{m}^{3}\right)\end{array}$ & $\begin{array}{c}\mathrm{NaOH} \\
\text { sol. } \\
\left(\mathrm{kg} / \mathrm{m}^{3}\right)\end{array}$ & $\begin{array}{c}\text { Free } \\
\text { Water } \\
\left(\mathbf{k g} / \mathbf{m}^{3}\right)\end{array}$ & $\begin{array}{c}\text { Sand } \\
0 / 4 \\
\left(\mathrm{~kg} / \mathrm{m}^{3}\right)\end{array}$ & $\begin{array}{c}\text { Gravel } \\
4 / 10 \\
\left(\mathrm{~kg} / \mathrm{m}^{3}\right)\end{array}$ & $\begin{array}{c}\text { Gravel } \\
10 / 20 \\
\left(\mathrm{~kg} / \mathrm{m}^{3}\right)\end{array}$ & $\begin{array}{c}\text { Theo. } \\
\text { density } \\
\left(\mathbf{k g} / \mathbf{m}^{3}\right)\end{array}$ & $\begin{array}{c}\text { Binder } \\
\text { content } \\
\left(\mathrm{kg} / \mathrm{m}^{3}\right)\end{array}$ & $\begin{array}{c}\text { Paste } \\
(\text { vol.\%) }\end{array}$ & $\begin{array}{c}\text { w/s } \\
\text { ratio }\end{array}$ \\
\hline $8 \mathrm{Cl}$ & 318 & 79 & 93 & 77 & 47 & 721 & 450 & 661 & 2446 & 397 & $33 \%$ & 0.35 \\
\hline $8 \mathrm{C} 2$ & 309 & 77 & 91 & 75 & 55 & 721 & 450 & 661 & 2439 & 387 & $33 \%$ & 0.37 \\
\hline $8 \mathrm{C3}$ & 301 & 75 & 89 & 73 & 62 & 721 & 450 & 661 & 2432 & 377 & $33 \%$ & 0.39 \\
\hline $8 \mathrm{C} 4$ & 294 & 73 & 86 & 71 & 69 & 721 & 450 & 661 & 2425 & 367 & $33 \%$ & 0.41 \\
\hline $8 \mathrm{C5}$ & 291 & 73 & 85 & 70 & 51 & 742 & 464 & 681 & 2457 & 363 & $31 \%$ & 0.37 \\
\hline $8 \mathrm{C6}$ & 283 & 71 & 83 & 68 & 58 & 742 & 464 & 681 & 2450 & 354 & $31 \%$ & 0.39 \\
\hline 8C7 & 276 & 69 & 81 & 67 & 64 & 742 & 464 & 681 & 2444 & 345 & $31 \%$ & 0.41 \\
\hline $8 C 8$ & 289 & 72 & 85 & 70 & 43 & 753 & 470 & 690 & 2472 & 361 & $30 \%$ & 0.35 \\
\hline 8C9 & 281 & 70 & 83 & 68 & 50 & 753 & 470 & 690 & 2465 & 351 & $30 \%$ & 0.37 \\
\hline $8 C 10$ & 274 & 68 & 81 & 66 & 56 & 753 & 470 & 690 & 2458 & 342 & $30 \%$ & 0.39 \\
\hline $8 C 11$ & 267 & 67 & 79 & 64 & 62 & 753 & 470 & 690 & 2452 & 334 & $30 \%$ & 0.41 \\
\hline
\end{tabular}

Table 4. Mix proportions for 60/40 fly ash/GGBS mixes (60/40).

\begin{tabular}{|c|c|c|c|c|c|c|c|c|c|c|c|c|}
\hline $\begin{array}{l}\text { Mix } \\
\text { label }\end{array}$ & $\begin{array}{l}\text { Fly ash } \\
\left(\mathrm{kg} / \mathrm{m}^{3}\right)\end{array}$ & $\begin{array}{c}\text { GGBS } \\
\left(\mathrm{kg} / \mathrm{m}^{3}\right)\end{array}$ & $\begin{array}{c}\text { SS sol. } \\
\left(\mathrm{kg} / \mathrm{m}^{\mathbf{3}}\right)\end{array}$ & $\begin{array}{c}\mathrm{NaOH} \\
\text { sol. } \\
\left(\mathrm{kg} / \mathrm{m}^{3}\right)\end{array}$ & $\begin{array}{c}\text { Free } \\
\text { Water } \\
\left(\mathrm{kg} / \mathrm{m}^{3}\right)\end{array}$ & $\begin{array}{c}\text { Sand } \\
0 / 4 \\
\left(\mathrm{~kg} / \mathrm{m}^{3}\right)\end{array}$ & $\begin{array}{c}\text { Gravel } \\
4 / 10 \\
\left(\mathrm{~kg} / \mathrm{m}^{3}\right)\end{array}$ & $\begin{array}{c}\text { Gravel } \\
10 / 20 \\
\left(\mathrm{~kg} / \mathrm{m}^{3}\right)\end{array}$ & $\begin{array}{c}\text { Theo. } \\
\text { density } \\
\left(\mathrm{kg} / \mathrm{m}^{3}\right)\end{array}$ & $\begin{array}{l}\text { Binder } \\
\text { content } \\
\left(\mathrm{kg} / \mathrm{m}^{3}\right)\end{array}$ & $\begin{array}{c}\text { Paste } \\
(\text { vol.\%) }\end{array}$ & $\begin{array}{c}\text { w/s } \\
\text { ratio }\end{array}$ \\
\hline $6 \mathrm{C1}$ & 239 & 159 & 94 & 77 & 52 & 721 & 450 & 661 & 2453 & 398 & $33 \%$ & 0.36 \\
\hline $6 \mathrm{C} 2$ & 230 & 153 & 90 & 74 & 63 & 721 & 450 & 661 & 2442 & 383 & $33 \%$ & 0.39 \\
\hline $6 \mathrm{C3}$ & 227 & 151 & 89 & 73 & 66 & 721 & 450 & 661 & 2438 & 378 & $33 \%$ & 0.40 \\
\hline $6 \mathrm{C} 4$ & 218 & 145 & 86 & 70 & 76 & 721 & 450 & 661 & 2427 & 364 & $33 \%$ & 0.43 \\
\hline $6 C 5$ & 219 & 146 & 86 & 70 & 56 & 742 & 464 & 681 & 2464 & 364 & $31 \%$ & 0.38 \\
\hline $6 \mathrm{C6}$ & 216 & 144 & 85 & 69 & 59 & 742 & 464 & 681 & 2460 & 360 & $31 \%$ & 0.39 \\
\hline $6 \mathrm{C} 7$ & 213 & 142 & 84 & 69 & 62 & 742 & 464 & 681 & 2457 & 355 & $31 \%$ & 0.4 \\
\hline $6 \mathrm{C8}$ & 209 & 139 & 82 & 67 & 57 & 753 & 470 & 690 & 2467 & 348 & $30 \%$ & 0.39 \\
\hline $6 \mathrm{C} 9$ & 203 & 136 & 80 & 65 & 63 & 753 & 470 & 690 & 2460 & 339 & $30 \%$ & 0.41 \\
\hline $6 \mathrm{C} 10$ & 198 & 132 & 78 & 64 & 69 & 753 & 470 & 690 & 2454 & 331 & $30 \%$ & 0.43 \\
\hline
\end{tabular}


Table 5. Mix proportions for 30/70 fly ash/GGBS mixes (30/70).

\begin{tabular}{|c|c|c|c|c|c|c|c|c|c|c|c|c|}
\hline $\begin{array}{c}\text { Mix } \\
\text { label }\end{array}$ & $\begin{array}{l}\text { Fly ash } \\
\left(\mathbf{k g} / \mathrm{m}^{3}\right)\end{array}$ & $\begin{array}{c}\text { GGBS } \\
\left(\mathbf{k g} / \mathrm{m}^{3}\right)\end{array}$ & $\begin{array}{l}\text { SS sol. } \\
\left(\mathbf{k g} / \mathbf{m}^{3}\right)\end{array}$ & $\begin{array}{c}\mathrm{NaOH} \\
\text { sol. } \\
\left(\mathrm{kg} / \mathrm{m}^{3}\right)\end{array}$ & $\begin{array}{c}\text { Free } \\
\text { Water } \\
\left(\mathrm{kg} / \mathrm{m}^{3}\right)\end{array}$ & $\begin{array}{c}\text { Sand } \\
0 / 4 \\
\left(\mathrm{~kg} / \mathrm{m}^{3}\right)\end{array}$ & $\begin{array}{c}\text { Gravel } \\
4 / 110 \\
\left(\mathrm{~kg} / \mathrm{m}^{3}\right)\end{array}$ & $\begin{array}{c}\text { Gravel } \\
10 / 20 \\
\left(\mathrm{~kg} / \mathrm{m}^{3}\right)\end{array}$ & $\begin{array}{c}\text { Theo. } \\
\text { density } \\
\left(\mathrm{kg} / \mathrm{m}^{3}\right)\end{array}$ & $\begin{array}{l}\text { Binder } \\
\text { content } \\
\left(\mathrm{kg} / \mathrm{m}^{3}\right)\end{array}$ & $\begin{array}{c}\text { Paste } \\
\text { (vol.\%) }\end{array}$ & $\begin{array}{c}\text { w/s } \\
\text { ratio }\end{array}$ \\
\hline $3 \mathrm{C} 1$ & 113 & 264 & 89 & 73 & 75 & 721 & 450 & 661 & 2446 & 377 & 33 & 0.42 \\
\hline $3 \mathrm{C} 2$ & 108 & 251 & 84 & 69 & 87 & 721 & 450 & 661 & 2431 & 359 & 33 & 0.46 \\
\hline $3 \mathrm{C3}$ & 105 & 245 & 82 & 68 & 93 & 721 & 450 & 661 & 2425 & 350 & 33 & 0.48 \\
\hline $3 \mathrm{C} 4$ & 106 & 248 & 83 & 68 & 70 & 742 & 464 & 681 & 2462 & 354 & 31 & 0.42 \\
\hline $3 \mathrm{C} 5$ & 101 & 236 & 79 & 65 & 82 & 742 & 464 & 681 & 2450 & 337 & 31 & 0.46 \\
\hline $3 \mathrm{C} 6$ & 99 & 230 & 77 & 63 & 87 & 742 & 464 & 681 & 2443 & 329 & 31 & 0.48 \\
\hline $3 \mathrm{C} 7$ & 103 & 240 & 81 & 66 & 68 & 753 & 470 & 690 & 2471 & 343 & 30 & 0.42 \\
\hline $3 \mathrm{C} 8$ & 98 & 228 & 77 & 63 & 79 & 753 & 470 & 690 & 2458 & 326 & 30 & 0.46 \\
\hline उC9 & 95 & 223 & 75 & 61 & 85 & 753 & 470 & 690 & 2452 & 318 & 30 & 0.48 \\
\hline
\end{tabular}

\subsection{Experimental procedures}

Compressive strength was determined on $100 \mathrm{~mm}$ concrete cubes tested with a $2000 \mathrm{kN}$ compression machine. The loading rate was set at $0.33 \mathrm{MPa} / \mathrm{s}$, in accordance with BS 1881-116:1983 [24]. The more current standard (BS EN 12390-3:2009) suggests a value of $0.6 \pm 0.2 \mathrm{MPa} / \mathrm{s}$. The slightly lower loading rate was not considered to have affected the results. Cubes produced with GGBS were cured at $20{ }^{\circ} \mathrm{C}$ in sealed containers $(>90 \%$ relative humidity, $\mathrm{RH})$. $\mathrm{RH}$ in the containers was monitored with the use of a portable digital humidity meter. $100 \%$ fly ash samples were cured unsealed in oven at $70{ }^{\circ} \mathrm{C}$ up till 28 days. Two cubes were tested at the testing age of 1,7 and 28 days. Some mixes were repeated for confirming the results. 3 cubes were tested instead of 2 for some mixes at each testing age (mixes $10 \mathrm{C} 1,10 \mathrm{C} 2,6 \mathrm{C} 1$ to $6 \mathrm{C} 10,3 \mathrm{C} 1,3 \mathrm{C} 4,3 \mathrm{C} 8$ ).

Initial and final setting times were measured on mortars according to the procedure described in the ASTM standard C403M - 08 [25]. The method determines the penetration force of a manual penetrometer in a mortar sample. Initial and final setting times correspond to required penetration pressures of $3.45 \mathrm{MPa}$ and $27.6 \mathrm{MPa}$ respectively.

\section{Results and discussion}

The design of a concrete mix requires the selection and correct proportions of binder, fine and coarse aggregate, water and other materials needed for producing concrete having the specified properties. This often involves a compromise between conflicting factors. Each mix ingredient may improve a property while adversely affecting others and the final proportioning must consider each and every effect if it is to result in the required concrete properties. The following sections examine and discuss the effects of mix parameters on workability, setting time and strength. 


\subsection{Effect of paste volume, GGBS content and w/s ratio on fresh and hardened properties of concrete}

\subsubsection{Effect on concrete consistency}

Results from slump tests on investigated fly ash/GGBS blends are shown in Figure 1.

Paste volume: the consistency of the mixes was found to be strongly influenced by the paste volume. The fresh consistency of AAC was dependent on the combined effect of paste and water content, whereas the lubrication effects responsible for the consistency of PC concretes are attributed mainly to the water content. It was observed that $30 \%$ paste volume normally resulted in slump values falling in classes S1 to S2, whereas for achieving fluid mixes (classes S3-S5) it was necessary to increase the paste volume. The paste is acting as the lubricant, and its effectiveness can be related to its (a) viscosity and (b) setting properties. These findings compare well with the results of previous studies in literature, i.e. (a) $400 \mathrm{~kg} / \mathrm{m}^{3}$ of binder was found to lead to greater than 18mm slump values [18], and (b) a correlation between consistency and paste content was found for slag-based AAC with greater than $450 \mathrm{~kg} / \mathrm{m}^{3}$ of binder [19].

GGBS content: increasing the GGBS content in general led to mixes of lower consistency unless w/s ratio was increased at the same time. High GGBS content (70\%) led to a significant reduction in the slump whilst the reduction for intermediate GGBS contents (20\% and $40 \%$ ) did not follow a well-defined trend because of scatter in the results. In general, it was observed that higher GGBS contents required higher w/s ratio for the mixes to be cast.

W/s ratio: even small changes in w/s ratio affected the slump values considerably. In general, increasing the w/s ratio resulted in an increase in the slump values. However, some decreases were observed as well. 


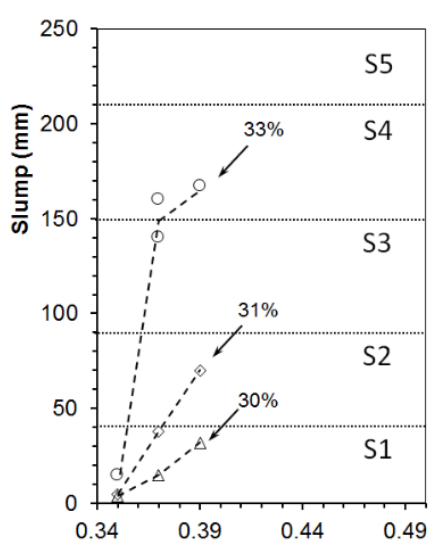

(a) 100/0 fly ash/GGBS

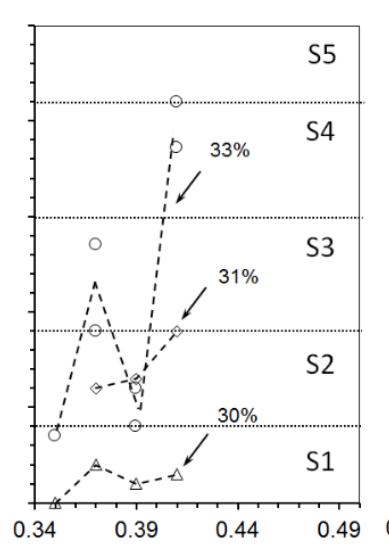

W/s ratio (-)

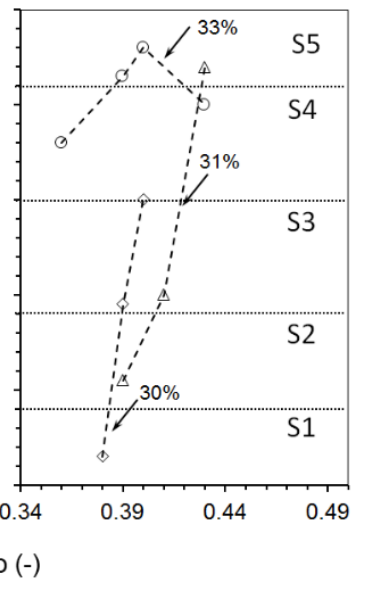

(c) $60 / 40$ fly ash/GGBS

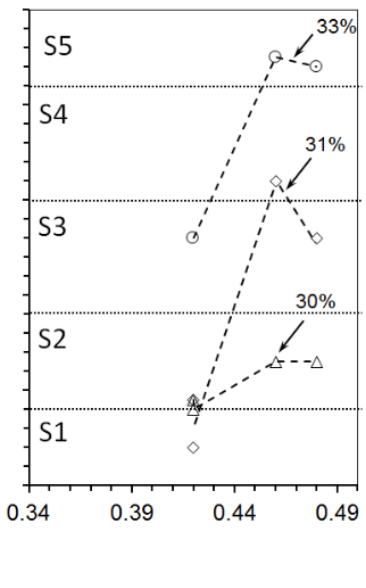

(d) 30/70 fly ash/GGBS

Figure 1. Slump values for the investigated blends. S1 to S5 refer to the slump classes defined in the European Standard BS EN 206:2013 [26]. Percentages refer to the paste volume.

\subsubsection{Effects on setting time}

ASTM standard C403M - 08 “Standard Test Method for Time of Setting of Concrete Mixtures by Penetration Resistance" [25] was developed for PC concrete and requires to sieve the wet concrete through a $4.75 \mathrm{~mm}$ sieve. In order not to lose initial points on the penetration vs. time curves due to sieving operations, it was decided to carry out the investigation on mortars prepared with dosages $\mathrm{M}+7.5 \%$ and $\mathrm{AM} 1.25$, assessing the effect of water content and GGBS content on setting. Mortars for each binder blend (80/20, 60/40 and 30/70 fly ash/GGBS) had sand : binder ratio equal to 2.75 and this resulted in a paste volume of about $49 \%$, which is not dissimilar to the value that would be obtained by sieving the concrete (in the range of $52 \%-55 \%$ ). The mix $100 / 0$, i.e. neat fly ash, was not investigated as fly ash alkali activated binders do not set at room temperature but require curing at high temperature.

Higher w/s ratios led to longer initial setting times. The increased water volume may have had a dilution effect which led to retarding the reaction [27]. Extremely low w/s ratios resulted in unsuitable initial setting times, e.g., less than 15 minutes with w/s ratios lower than 0.37 measured for 60/40 mixes.

Increasing GGBS content resulted in reducing the initial setting time, as was expected from what has been reported in the literature [20]. Figure 2 shows the initial and final setting times versus w/s ratio. It can be seen that the higher the GGBS content, the shorter the setting time is, and therefore the water content has to be increased to maintain the mix workable for longer times. These findings further confirmed the need for increasing w/s ratio while increasing GGBS content in the mix, as previously discussed. Data points of low w/s ratios that led to extremely low initial setting times shown in circles in Figure 2a are considered to be outliers. 

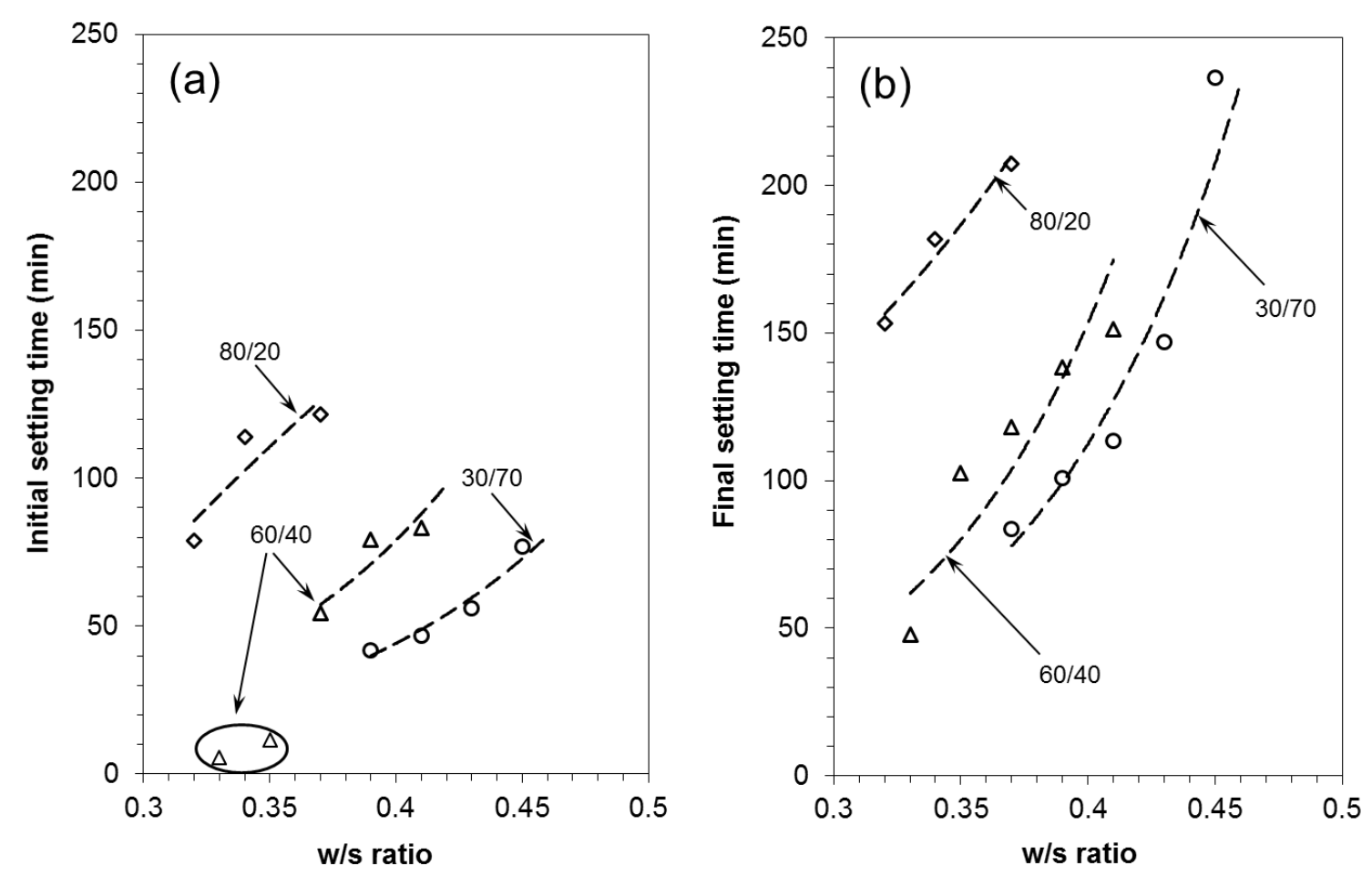

Figure 2. Combined results for tested blends. (a) Initial setting time vs. w/s ratio, (b) final setting time vs. w/s ratio.

\subsubsection{Effect on compressive strength}

Figure 3 shows the results of compressive strength tests on AAC. The effects of paste volume, GGBS content and $w / s$ ratio are:

Paste volume: paste volume of $30 \%$ to $33 \%$ was found to have little influence on the compressive strength. In most of the cases, variations in strength due to variation in the paste volume were within the range of variability of experimental data.

GGBS content: GGBS content had a high influence on the compressive strength. Changing the fly ash/GGBS ratio resulted in concrete with a wide range (20 to $80 \mathrm{MPa}$ ) of compressive strengths: $12-20 \mathrm{MPa}$ for 100/0 fly ash/GGBS mixes, 30 - $40 \mathrm{MPa}$ for 80/20 mixes, 50 - $60 \mathrm{MPa}$ for $60 / 40$ mixes, and 65 - $75 \mathrm{MPa}$ for 30/70 mixes. Increasing GGBS also increased the early age strength, i.e. the ratio between 7-day and 28-day strengths was about $60 \%$ for $80 / 20$ mixes, $70 \%$ for $60 / 40$ mixes, and $80 \%$ for $30 / 70$ mixes.

W/s ratio: increasing w/s ratio adversely affected the compressive strength. The effect is more noticeable for neat fly ash AAC, i.e. 100/0 mixes (see Figures 3 a1-a3), where the w/s ratio has an almost linear relationship with the compressive strength. Similar trends have been reported in the literature [5]. Increasing the w/s ratio from 0.35 to 0.39 resulted in a strength reduction of about $50 \%$ irrespective of the paste volume. The strength 
reduction with the increase in w/s ratio may be attributed to the increased porosity resulting from water evaporation from the pores, as described in the literature [28]. The curing regime (i.e. oven curing at $70{ }^{\circ} \mathrm{C}$ ) may also have contributed to fast evaporation of water. The higher the w/s ratio, the more porous the final structure was. Addition of GGBS seems to reduce the effect of w/s ratio on the compressive strength, and this trend has also been reported by others [19]. Detrimental effects of water inclusion in 80/20 FA/GGBS mixes were more noticeable for higher w/s ratios $(0.39$ to 0.41$)$ than they were for lower w/s ratio $(0.35$ to 0.37$)$, where there was no substantial decrease (see Figures 3 b1-b3). For 60/40 mixes higher values of w/s ratios had considerable strength reductions whilst only moderate reductions were seen for w/s ratio less than 0.41 . Strength reductions of as high as $40 \%$ were observed in mixes with paste content equal to $30 \%$ when the w/s ratio was increased above 0.41 (see Figures 3 c1-c3). However, increasing of w/s ratio from 0.42 to as high as 0.48 for $30 / 70$ mixes did not seem to affect considerably the strengths which were greater than $60 \mathrm{MPa}$ (see Figures $3 \mathrm{~d} 1$-d3). 24-hour strengths as high as $30 \mathrm{MPa}$ were achieved for w/s ratio of 0.42 .

Mixes 100/0 which were neat fly ash required oven curing at $70{ }^{\circ} \mathrm{C}$. 28-day and 7 -day strengths were comparable, indicating that the reaction is nearly complete within 7 days. Drying of the samples especially with high w/s ratio for longer than 7 days may have affected strengths. For w/s ratio of 0.39 , the compressive strength at 28 days was even found to be lower than the 7-day strength.

All the strength data obtained, irrespective of paste volume, have been replotted on a single graph, see Figure 4. This confirms that the paste volume does not affect significantly the strength in the investigated range. The regression lines through the data points, i.e. the dashed lines, show the relationship between compressive strength and w/s ratio. The grey lines shown are from the BRE method for the design of normal concrete mixes and they show the relationship between compressive strength and water/cement ratio (w/c) [29]. 


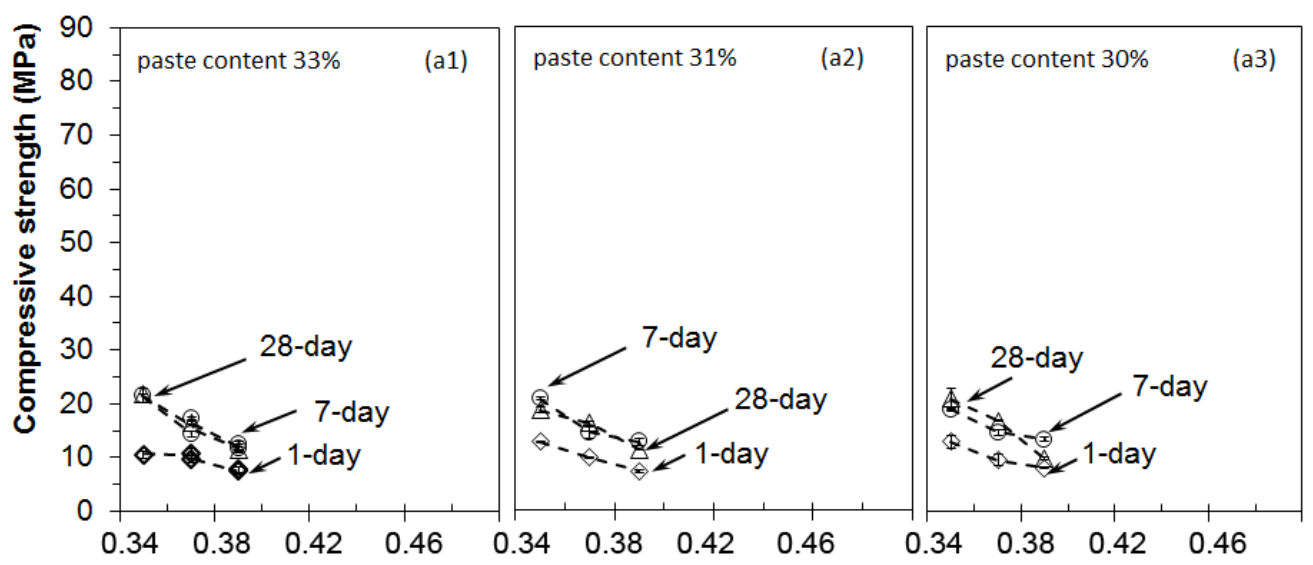

(a) $100 / 0$ fly ash/GGBS

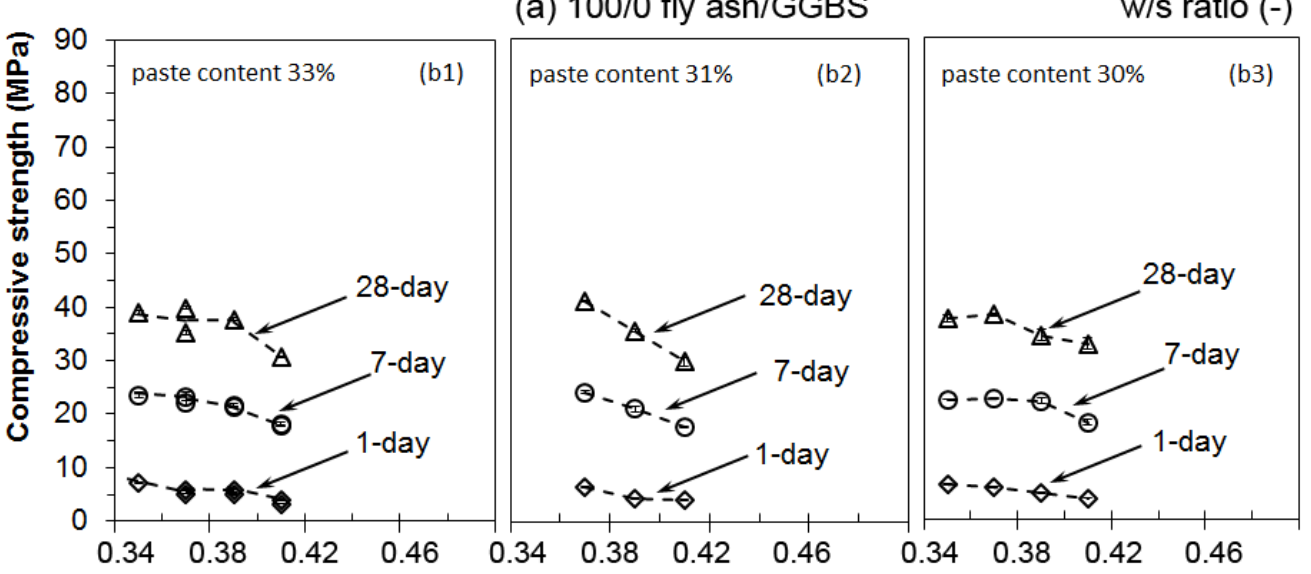

(b) $80 / 20$ fly ash/GGBS

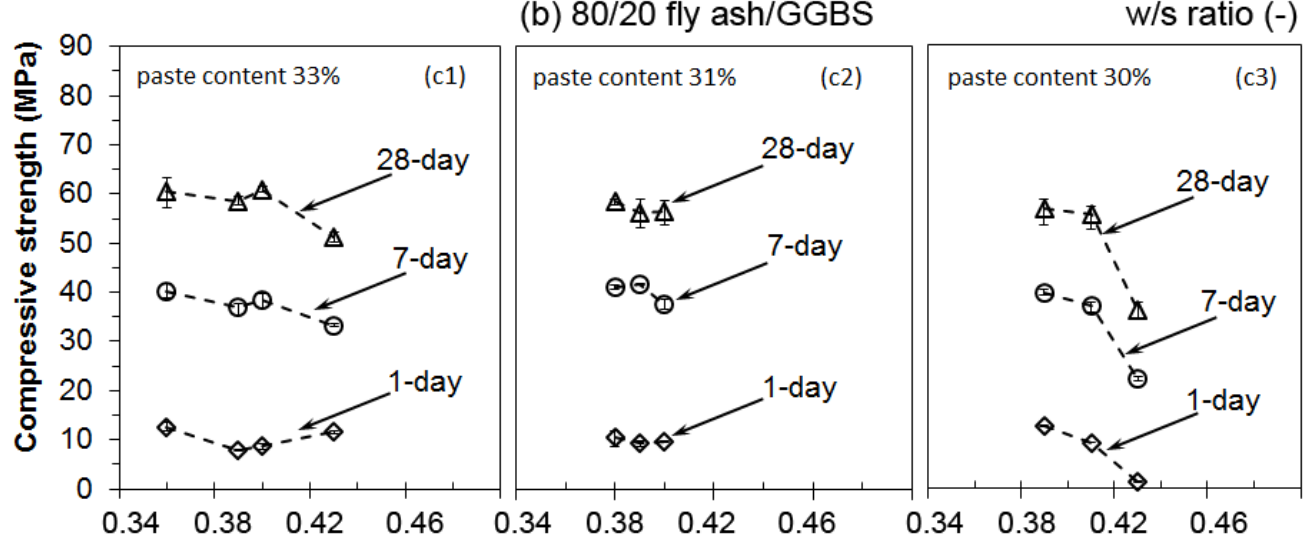

(c) $60 / 40$ fly ash/GGBS

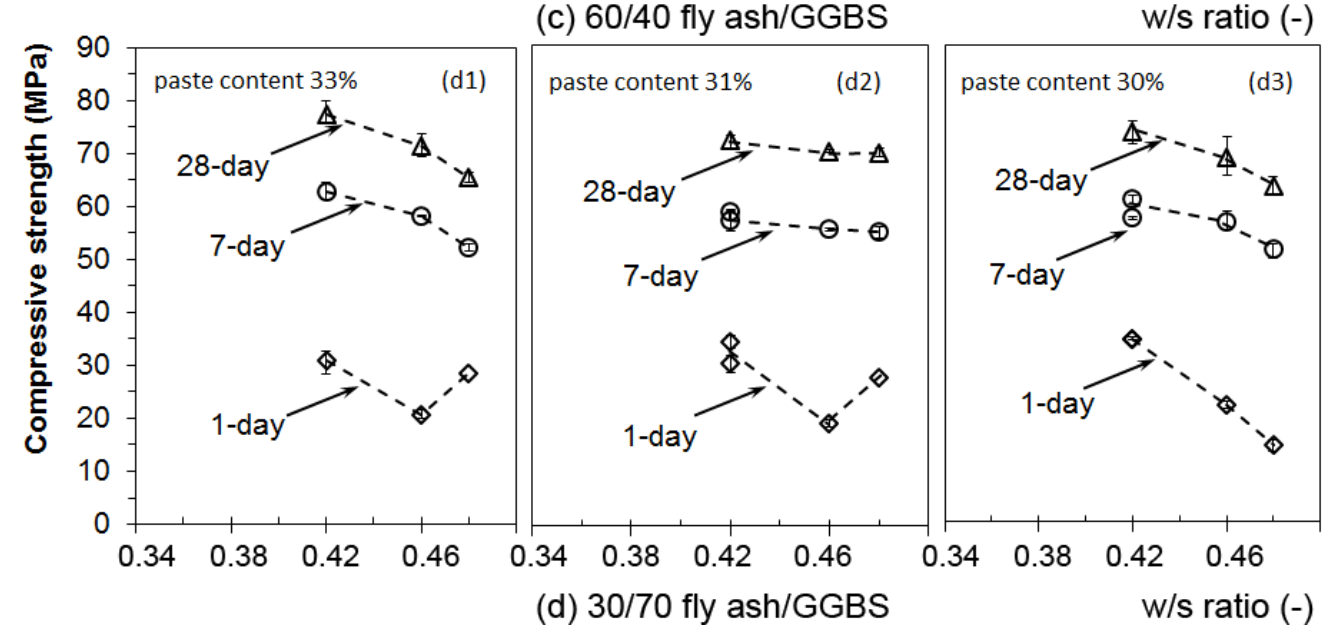

Figure 3. Compressive strength test results. 


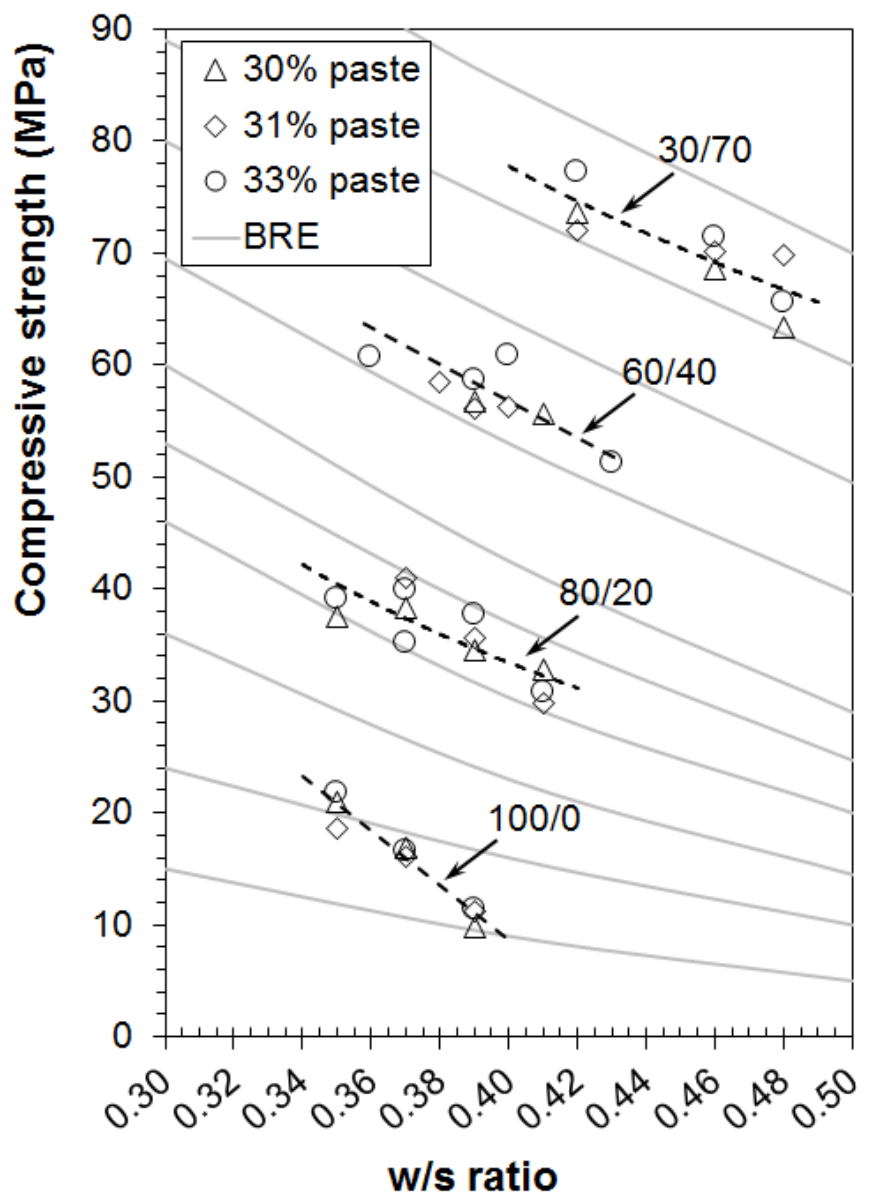

Figure 4. Summary of 28-day compressive strengths for the investigated blends.

The relationships for w/s ratio for AAC follow the same trends as for w/c ratio for Portland cement mixes. The only one that has a steeper slope is for $100 \%$ fly ash mixes and these mixes were cured at $70{ }^{\circ} \mathrm{C}$ while all the others were cured at room temperature, i.e. $20^{\circ} \mathrm{C}$.

\subsection{Guidelines for mix proportioning of AAC}

Alkali activated concrete is often regarded as a potential solution for the reduction of $\mathrm{CO}_{2}$ emission of the construction sector. However, costs and environmental impacts associated with the chemical activators can be very high and can hinder the commercialisation of AAC. A suitable mix design procedure is necessary for ensuring low environmental burden and cost-effective production [30].

The procedure for deriving the mix proportions for a concrete with desired properties has to take into account the effect of several factors such as fresh and hardened properties which are sometimes conflicting. The results discussed in the previous sections were combined for defining a simple step-by-step empirical method for mix proportioning of AAC. Properties considered are consistency class, setting time and compressive strength. A set 
of "design" charts for the application of the method was developed from the experimental results described above:

- Figure 5 can be used as a "design" chart for a preliminary estimation of the fly ash/GGBS ratio for any compressive strength. It contains also information relating to setting time described above in section 3.1.2. It is to be noted that not all the combinations of compressive strength/initial setting time can be obtained because there are regions representing fast setting or sudden strength reduction due to high w/s ratios. The relationship between strength and GGBS content has been reported to be almost linear [23]. Therefore, relationships between w/s ratio and 28-day compressive strength for intermediate fly ash/GGBS content can be inferred from the trends shown in Figure 4.

- Figure 6 can be used for checking the predicted initial setting time from w/s ratio and binder blend.

- $\quad$ Figure 7 can be used for the determination of the paste volume for obtaining the desired consistency class after having selected the w/s ratio and the binder blend.

- Volume of binder, activator, and water makes up the paste volume. Binder content (expressed in $\mathrm{kg} / \mathrm{m}^{3}$ ) can be calculated from paste volume, w/s ratio, binder blend, activator dosages, together with the densities of each constituent. The design chart in Figure 8 can be used for the determination of the binder content. It is however based on the constituents used in this research. Relationships between binder content and other parameters being linear, interpolation can be used for intermediate paste volumes and w/s ratios. 


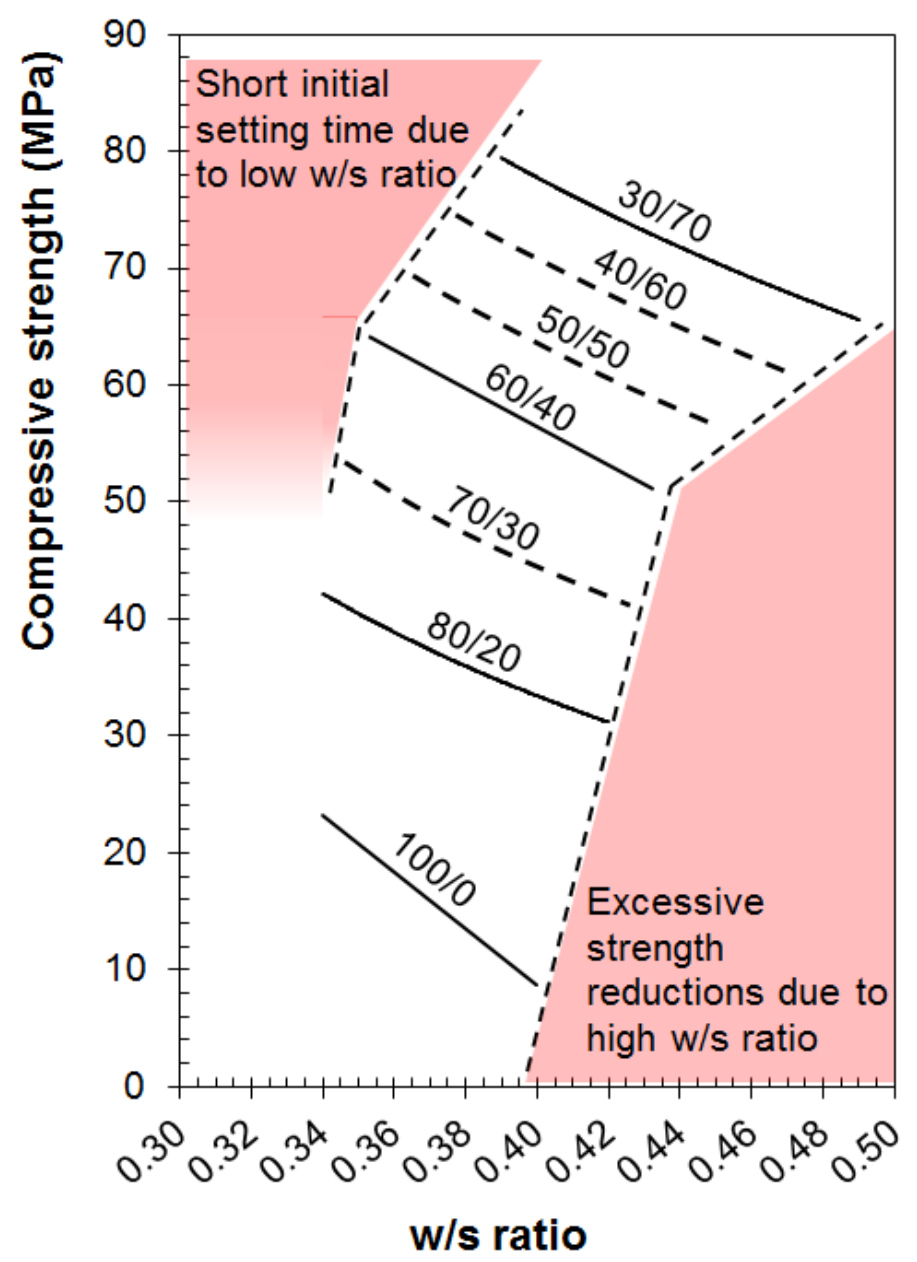

Figure 5. Design chart - relationship between compressive strength, w/s ratio and fly ash/GGBS blend. 


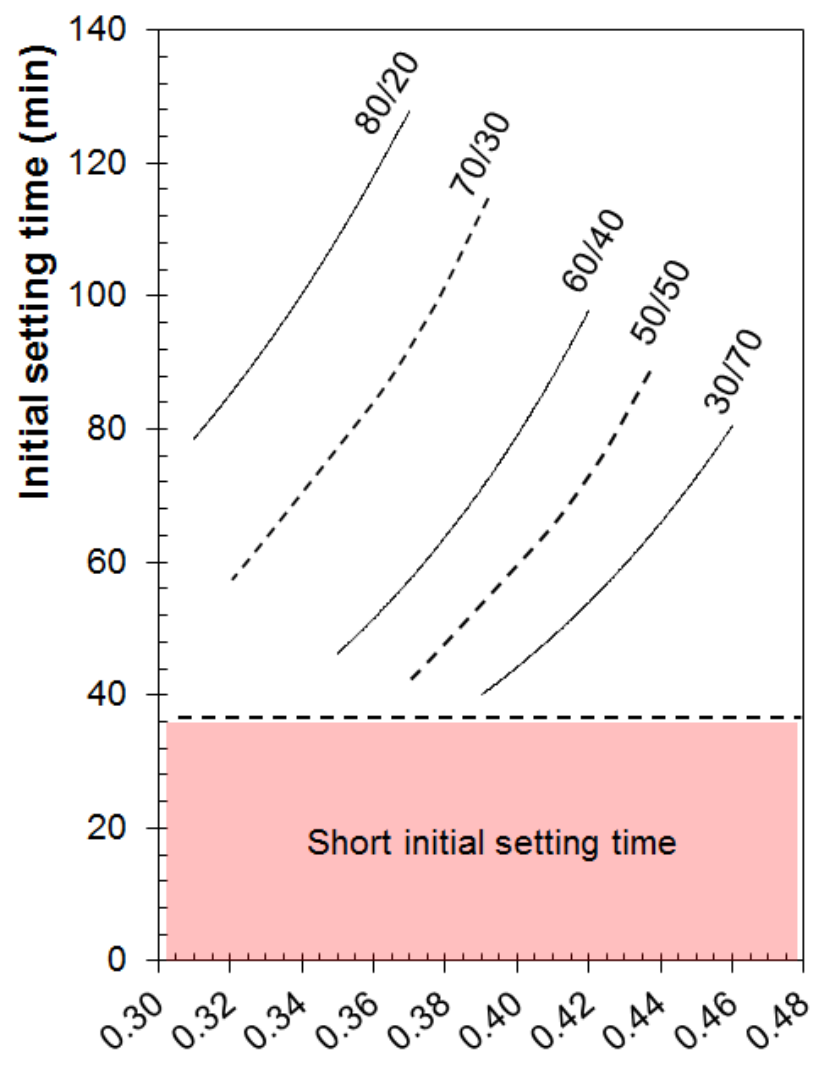

w/s ratio

Figure 6. Design chart - initial setting time vs. w/s ratio for a range of fly ash/GGBS ratios.

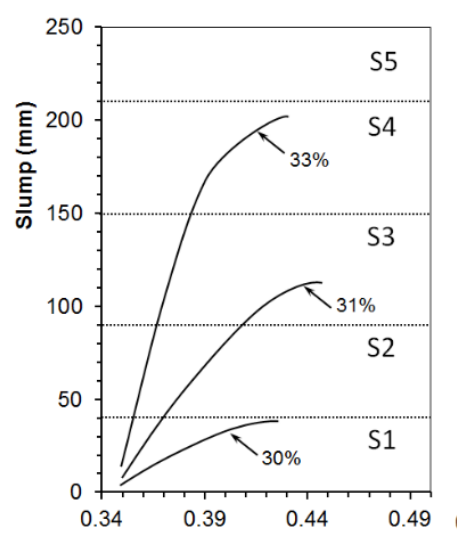

(a) 100/0 fly ash/GGBS

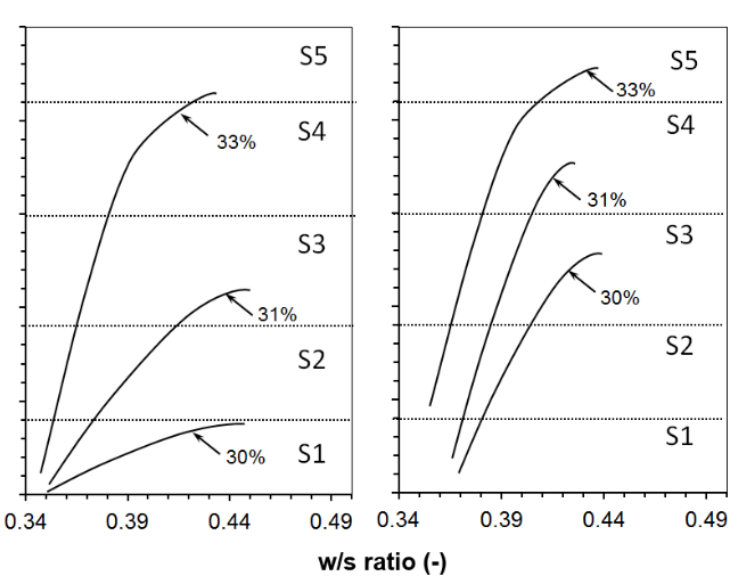

(b) $80 / 20$ fly ash/GGBS

(c) $60 / 40$ fly ash/GGBS

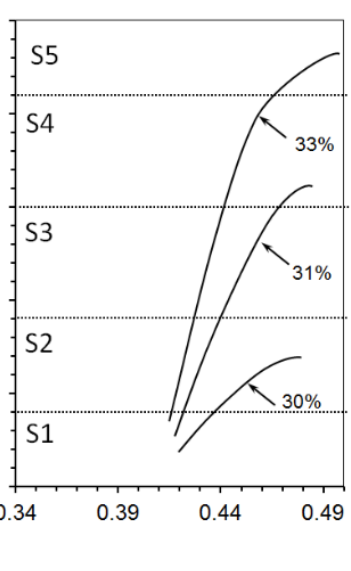

(d) 30/70 fly ash/GGBS

Figure 7. Design chart - relationship between consistency classes, binder blends and paste volume. 


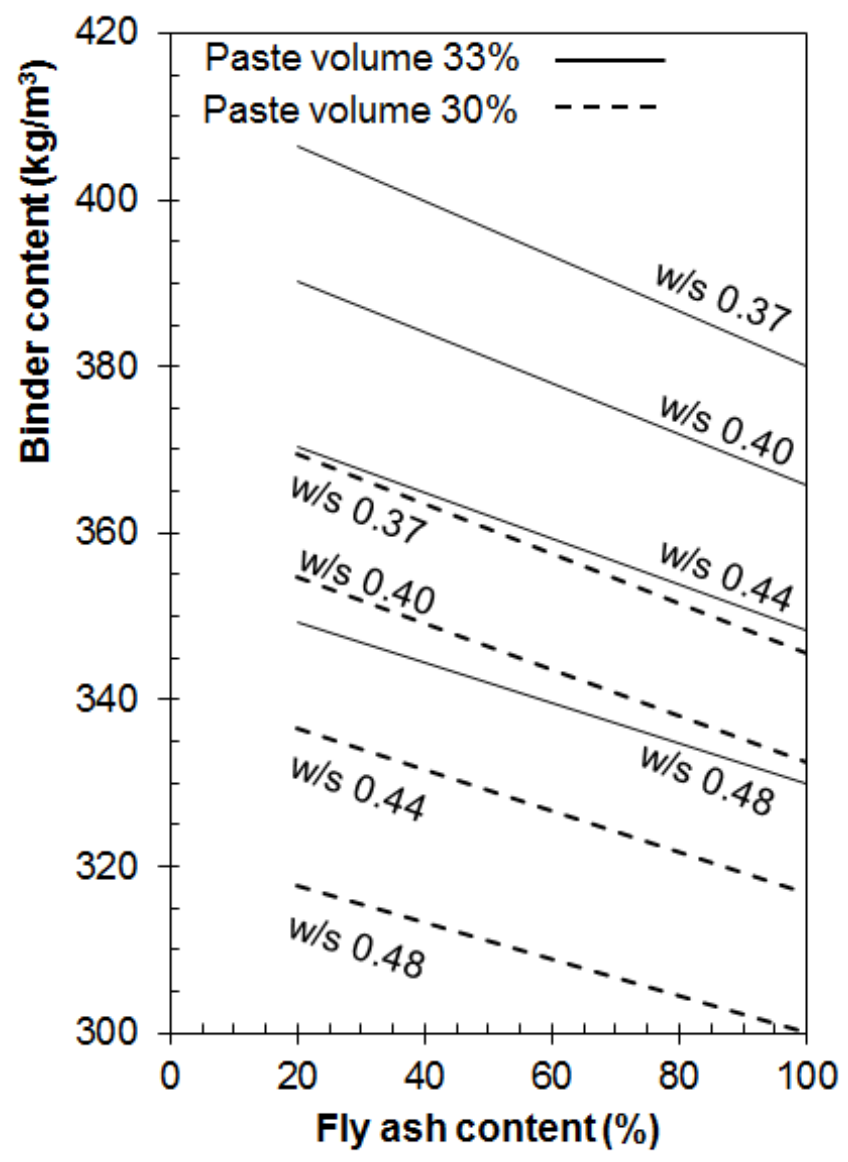

Figure 8. Design chart - determination of binder content from fly ash/GGBS blend, w/s ratio and paste volume.

The steps required to select mix proportions for a trial mix are shown in Figure 9 as a flow chart and described below:

Step - 01. Specification of required properties, i.e. compressive strength, initial setting time and consistency class.

Step - 02. Determination of fly ash/GGBS blend and w/s ratio. A horizontal line corresponding to the required strength is drawn on Figure 5, crossing one of the relationships between blend and w/s ratio. It may be necessary to interpolate in order to obtain a blend for the required strength.

Step - 03. Check of the compliance with required initial setting time from Figure 6, using w/s ratio and fly ash/GGBS blend obtained in above step. In the case where the initial setting time is less than required, then iterate step-03 increasing the GGBS content in the blend and obtaining a new set of values for fly ash/GGBS blend and w/s ratio. A small increase of GGBS content allows a significant increase of the w/s ratio for obtaining the desired compressive strength, and such increase of w/s ratio should lead to a longer initial setting time. 
Step - 04. Determination of the paste volume for achieving the required consistency. A suitable paste volume is obtained from Figure 7 according to the w/s ratio, fly ash/GGBS blend and the required consistency class. If this latter can be achieved with more than one paste volume, lower paste volume is preferred as this implies lower quantities of binder and activators. Chemicals for activation contribute significantly to production costs as well as the carbon footprint of AAC [30] and therefore choosing the lowest paste volume would contribute to lowering both.

Step - 05. Determination of binder content (expressed in $\mathrm{kg} / \mathrm{m}^{3}$ ) from Figure 8 , using fly ash/GGBS blend, w/s ratio, and paste volume obtained from previous steps.

Step - 06. Determination of the quantities of $\mathrm{Na}_{2} \mathrm{O}$ and $\mathrm{SiO}_{2}$ from the binder mass for $\mathrm{M}+=7.5 \%$ and $\mathrm{AM}=$ 1.25. Quantities of chemicals should then be calculated according to the actual compositions of the activators, which might differ from supplier to supplier.

Step - 07. Determination of the mass of water required. The water to be added in the mix is calculated from binder mass, $\mathrm{Na}_{2} \mathrm{O}$ and $\mathrm{SiO}_{2}$ mass, and w/s ratio, taking into account the water already included in the chemical solutions (i.e. the water in the silicate solution and in the $\mathrm{NaOH}$ solution).

Step - 08. Determination of the aggregate quantities. Volume of aggregates is obtained by subtracting the paste volume from $1 \mathrm{~m}^{3}$ of concrete. The mass of each aggregate size is determined from the relative $\%$ proportion to be used.

This procedure is a simple method for the determination of the trial mix proportions for AAC to achieve the required properties of strength, consistency and initial setting time. This method is based on empirical data, as is the BRE method [29], and a trial mix is required to confirm or otherwise that the concrete mix has or not the required properties. The trial mix can then be refined. 


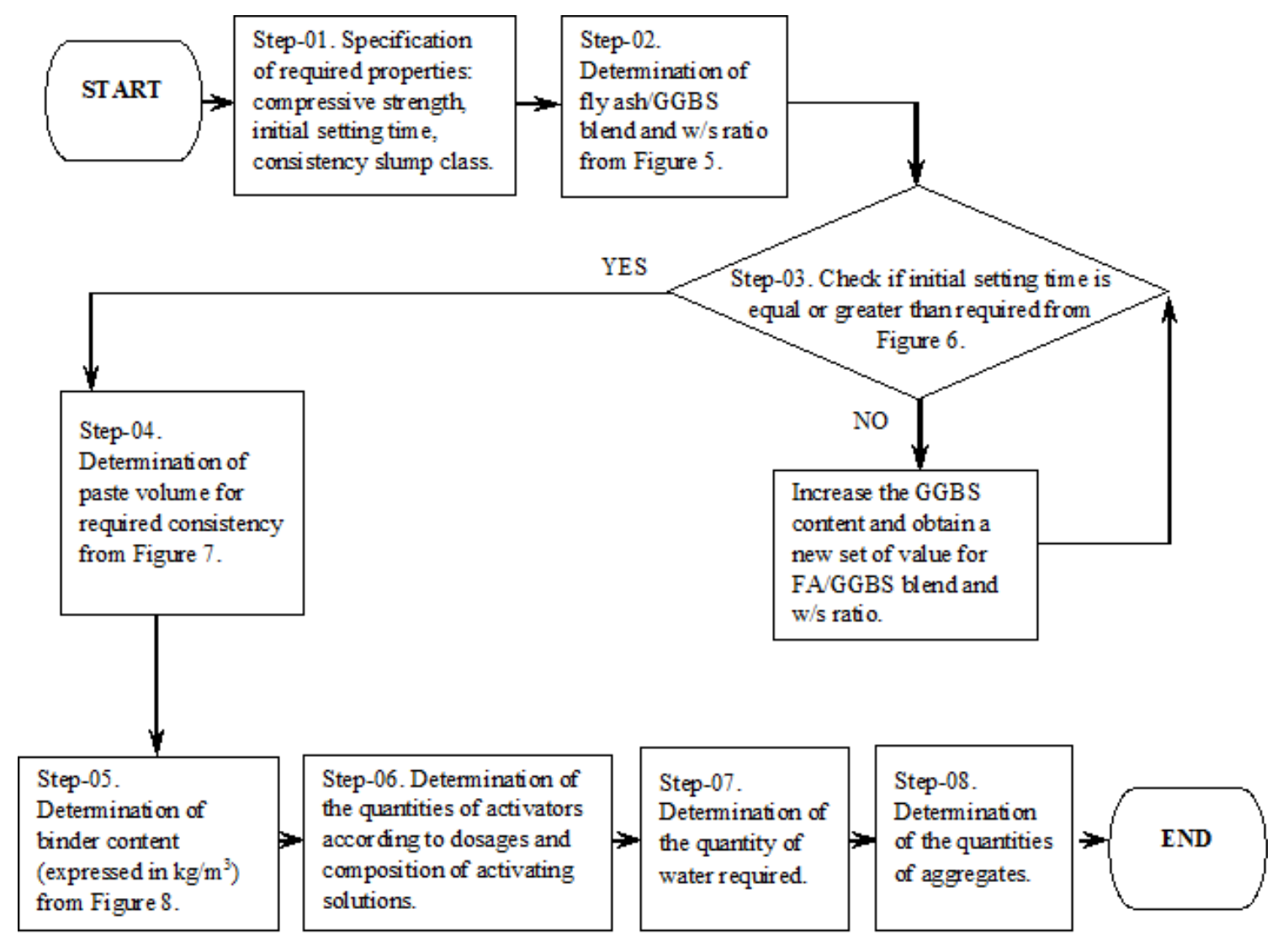

Figure 9. Flow chart for the application of the mix design procedure.

\subsection{Examples of AAC mix design and comparison with PC}

The mix design procedure can be applied for a range of applications of AAC. Three concretes with different requirements are used as examples.

- A typical ready mix concrete, with cube compressive strength of $35 \mathrm{MPa}$, initial setting time higher than 2 hours and consistency class S2, hereafter referred to as AAC-35.

- A typical structural concrete with cube compressive strength $50 \mathrm{MPa}$, initial setting time higher than 90 minutes and consistency class $\mathrm{S} 2$, labelled AAC-50.

- A high strength mix for precast concrete applications, with cube compressive strength of $70 \mathrm{MPa}$, initial setting time higher than 1 hour and consistency class S2, labelled AAC-70.

Trial mix proportions determined using Figure 9, for the three concretes, are shown in Table 6. The binder content depends on the paste volume, on the fly ash/GGBS blend and on the w/s ratio. AAC with same paste volume and same w/s ratio but different fly ash/GGBS ratio would have different binder content as fly ash and GGBS have different densities. 
In order to carry out a comparison between $\mathrm{AAC}$ and traditional Portland cement concrete (PC), mix proportions for PC with similar properties were determined according to the BRE procedure [29]. Results are shown in Table 7 alongside the AAC mix proportions.

Table 6. Mix proportions for the AAC examples as per the developed procedure.

\section{Step}

AAC-35 AAC-50 AAC-70

Step - 01. Specification of required properties

$\begin{array}{rccc}\text { Compressive strength (MPa) } & 35 & 50 & 70 \\ \text { Consistency class } & \mathrm{S} 2 & \mathrm{~S} 2 & \mathrm{~S} 2 \\ \text { Initial setting time (minutes) } & 120 & 90 & 60\end{array}$

Step - 02. Determination of fly ash/GGBS blend and w/s ratio (Fig. 5)

$\begin{array}{rccc}\text { fly ash/GGBS blend } & 80 / 20 & 70 / 30 & 30 / 70 \\ \text { w/s ratio } & 0.39 & 0.37 & 0.45\end{array}$

Step - 03. Compliance with required initial setting time (Fig. 6)

Step - 04. Paste volume for the required consistency (Fig. 7)

$31 \% \quad 31 \% \quad 30 \%$

Step - 05. Determination of binder content $\left(\mathrm{kg} / \mathrm{m}^{3}\right)$ (Fig. 8)

$354 \quad 369 \quad 330$

Step - 06. Determination of the quantities of $\mathrm{Na}_{2} \mathrm{O}$ and $\mathrm{SiO}_{2}$

$\begin{array}{cccc}\mathrm{Na}_{2} \mathrm{O}(\text { from } \mathrm{M}+=7.5 \%) & 26.55 & 27.60 & 24.75 \\ \mathrm{SiO}_{2}(\text { From } \mathrm{AM}=1.25) & 21.24 & 22.08 & 19.8\end{array}$

$\begin{array}{llll}\text { Quantity of silicate solution (SS) according to solution composition }\left(\mathrm{kg} / \mathrm{m}^{3}\right) & 83.2 & 86.7 & 77.7\end{array}$

Quantity of $\mathrm{NaOH}\left(\mathrm{kg} / \mathrm{m}^{3}\right) \quad 20.5 \quad 21.4 \quad 19.1$

Step - 07. Determination of the quantity of water to be added

$105.8 \quad 99.8 \quad 121.2$

Step - 08. Determination of the quantities of aggregates

$1887 \quad 1887$

Table 7. Comparison of mix proportions for PC and AAC of similar cube compressive strength.

\begin{tabular}{lcccccc}
\hline \multicolumn{1}{c}{ Constituent } & PC-35 & AAC-35 & PC-50 & AAC-50 & PC-70 & AAC-70 \\
\hline Binder content $\left(\mathrm{kg} / \mathrm{m}^{3}\right)$ & 355 & 354 & 440 & 369 & 550 & 330 \\
w/c ratio (-) & 0.62 & 0.39 & 0.50 & 0.37 & 0.40 & 0.45 \\
Free water content $\left(\mathrm{kg} / \mathrm{m}^{3}\right)$ & 220 & $157^{*}$ & 220 & $153^{*}$ & 220 & $169^{*}$ \\
Paste volume (\%) & $33 \%$ & $31 \%$ & $36 \%$ & $31 \%$ & $39 \%$ & $30 \%$ \\
Quantities of aggregate $\left(\mathrm{kg} / \mathrm{m}^{3}\right)$ & 1832 & 1887 & 1750 & 1887 & 1668 & 1914 \\
\hline
\end{tabular}

* this value refers to the total amount of water, i.e. added water plus water included in the sodium silicate solution.

The following can be noted when comparing the AAC to the "equivalent" PC mixes:

- The binder content for the three AACs does not significantly increase with increasing the compressive 
strength. The binder content of AAC is in the range of 330 to $370 \mathrm{~kg} / \mathrm{m}^{3}$ for all three strength grades, whilst that of PC concretes varies from 355 to $550 \mathrm{~kg} / \mathrm{m}^{3}$. The compressive strength of AAC mixes is determined by the amount of GGBS in the blend, and, to a lesser extent, by the w/s ratio. GGBS increases from just $20 \%$ for AAC-35 to $70 \%$ for AAC-70.

- W/s ratio for AAC concretes is dependent on the fly ash/GGBS ratio, on the required initial setting time and, to a lesser extent, on the required compressive strength. When GGBS content is low, w/s ratio is significantly lower than the w/c ratio required for PC concretes.

- The ratio of free water contents between AAC and PC equivalent concretes is in the range $70 \%$ to $77 \%$.

- Paste volume for AAC concretes is between $30 \%$ and $31 \%$, which is consistent with the void content of the aggregate blend $(34 \%$ and $22 \%$ in loose and compacted state respectively, as discussed in section 2.1 above), i.e. greater than the minimum void content for ensuring adequate consistency and smaller than the maximum void content for avoiding excess paste. Paste volume for PC concretes is always higher than AAC concretes, which seems to indicate that the paste in AAC is more fluid, presumably due to the presence of sodium silicate. The paste volume obtained for PC-70 is very high (39\%), and in the practice it would be reduced by adding admixtures to obtain the desired consistency whilst reducing the cement content (which is determined by the w/c ratio). However, in this study no admixture was considered in order to carry out a direct comparison between AAC and PC concretes.

- Quantities of aggregate are not dissimilar when comparing AAC-35 and PC-35. For higher strength grades, the increase of the paste volume resulted in a reduction of aggregate volume for PC concretes which was not the case for AAC concretes.

- Mix data for PC concretes were obtained without considering the use of admixtures, which would reduce the water demand for achieving the target consistency and consequently would reduce the cement content in the mix.

\subsection{Experimental validation}

AAC concrete mix proportions from the procedure above were tried in the laboratory. A comparison between fresh and hardened "design" properties and the actual experimentally obtained are shown in Table 8 . Compressive strengths at 28 days for AAC-35 and AAC-70 were slightly lower than the "design" values. Results were within a $10 \%$ variation from the target. A slight reduction of the w/s ratio would allow to achieve the desired strength without affecting considerably the initial setting time. 
The slump value was satisfactory for AAC-35 and AAC-70, whereas it was only $10 \mathrm{~mm}$ for AAC-50. The slump value could be increased by increasing the paste volume from $31 \%$ to $32 \%$. Values of initial setting times, measured on mortars according to the ASTM standard C403M - 08 [25] were satisfactory.

Table 8. Comparison between "design" and experimentally obtained values. Values in brackets represent deviation from average.

\begin{tabular}{lcccccc}
\hline \multirow{2}{*}{ Requirement } & \multicolumn{2}{c}{ AAC-35 } & \multicolumn{2}{c}{ AAC-50 } & \multicolumn{2}{c}{ AAC-70 } \\
& "Design" & Actual & “Design” & Actual & “Design” & Actual \\
\hline Compressive strength at 28 days (MPa) & 35 & $31.7(0.96)$ & 50 & $50.3(3.22)$ & 70 & $64.3(0.81)$ \\
Slump (mm) & $50-90$ & 70 & $50-90$ & 10 & $50-90$ & 50 \\
Initial setting time (minutes) & $>120$ & 181 & $>90$ & 109 & $>60$ & 77 \\
\hline
\end{tabular}

It may therefore be concluded that the mix proportions from the above procedure were satisfactory for a trial mix which could then be further improved.

\subsection{Cost analysis}

In order to assess the economic viability of $\mathrm{AAC}$, a cost analysis was carried out for the above concrete mixes comparing the AAC with the PC ones.

The cost of the concrete is largely dependent on the costs of the constituents, mainly Portland cement, fly ash, GGBS, sodium hydroxide and sodium silicate solution. Prices for constituents are not easy to obtain as they depend on several factors:

- Location: prices for materials can vary from one country to another, due to fluctuating market forces, the stock availability, the traders and the producers. This is particularly true for cement, which can have price differences even between locations within one country.

- Timing: price fluctuations over time can be considerable, since for most of the investigated materials the price is influenced by the cost of energy, in particular crude oil.

- Quantity: bulk purchases usually result in lower cost, in particular for chemicals, and the difference between the price of small and large quantities can be significant. The bulk purchase price is also usually negotiated with the supplier, and it is not readily disclosed.

Tentative prices for each constituent were obtained through contacts with industry, quotations and searches on trading websites and these can be considered representative for bulk purchase in the UK market. Prices are shown in Table 9 along with quantities for the production of $1 \mathrm{~m}^{3}$ of concrete for the mix proportions obtained 
in the previous section. The cost for AAC-35 and AAC-70 does not differ considerably. This is due to the fact that the most costly constituents are chemicals whose quantities are similar in the two concrete strength classes. The strength class is related to the GGBS content. The low w/s ratio for AAC-50 resulted in higher binder content, with a slightly higher cost due to the amounts of chemicals and precursors.

The price for PC concretes, on the other hand, depended on the strength grade. The most expensive constituent is Portland cement, and increasing compressive strengths requires lower w/c ratios and thus higher cement contents if plasticisers are not used. Portland cement accounted for $57 \%$ to $70 \%$ of the total cost of the concrete. Figure 10 shows the cost breakdown for the AAC and PC concretes.

Table 9. Price breakdown and total estimated price for $1 \mathrm{~m}^{3}$ of AAC and PC concretes.

\begin{tabular}{lccccccc}
\hline \multicolumn{1}{c}{ Constituent } & $\begin{array}{c}\text { Estimated } \\
\text { price }(\mathfrak{f} / \mathrm{t})\end{array}$ & $\begin{array}{c}\text { AAC-35 } \\
\left(£ / \mathrm{m}^{3}\right)\end{array}$ & $\begin{array}{c}\text { AAC-50 } \\
\left(£ / \mathrm{m}^{3}\right)\end{array}$ & $\begin{array}{c}\text { AAC-70 } \\
\left(£ / \mathrm{m}^{3}\right)\end{array}$ & $\begin{array}{c}\text { PC-35 } \\
\left(£ / \mathrm{m}^{3}\right)\end{array}$ & $\begin{array}{c}\text { PC-50 } \\
\left(£ / \mathrm{m}^{3}\right)\end{array}$ & $\begin{array}{c}\text { PC-70 } \\
\left(£ / \mathrm{m}^{3}\right)\end{array}$ \\
\hline Portland cement & 70 & - & - & - & 24.85 & 30.80 & 38.50 \\
Fly ash & 40 & 11.33 & 10.33 & 3.96 & - & - & - \\
GGBS & 55 & 3.89 & 6.09 & 12.71 & - & - & - \\
SS solution & 250 & 20.82 & 21.71 & 19.41 & - & - & - \\
NaOH (solid) & 150 & 3.08 & 3.21 & 2.87 & - & - & - \\
Water & 1 & 0.11 & 0.10 & 0.12 & 0.22 & 0.22 & 0.22 \\
Aggregate & 10 & 18.98 & 18.98 & 19.25 & 18.32 & 17.50 & 16.68 \\
\hline Concrete cost $\left(\mathfrak{(} / \mathbf{m}^{\mathbf{3}}\right)$ & & $\mathbf{5 8 . 2 0}$ & $\mathbf{6 0 . 4 1}$ & $\mathbf{5 8 . 3 1}$ & $\mathbf{4 3 . 3 9}$ & $\mathbf{4 8 . 5 2}$ & $\mathbf{5 5 . 4 0}$ \\
\hline
\end{tabular}




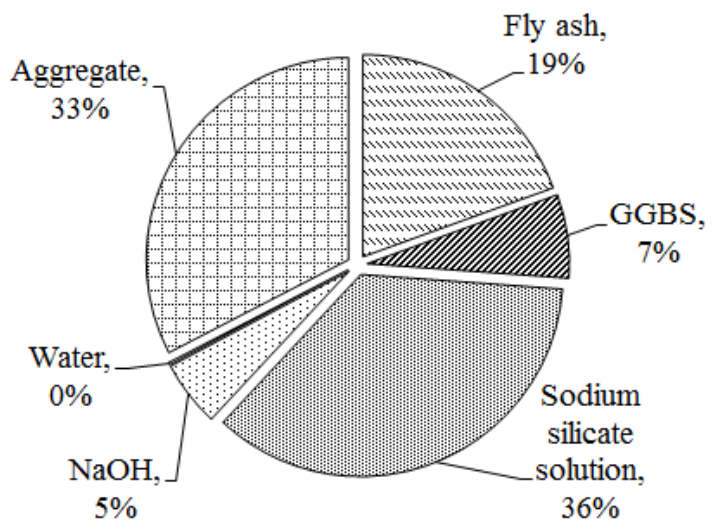

(a) AAC - $35 \mathrm{MPa}$ concrete

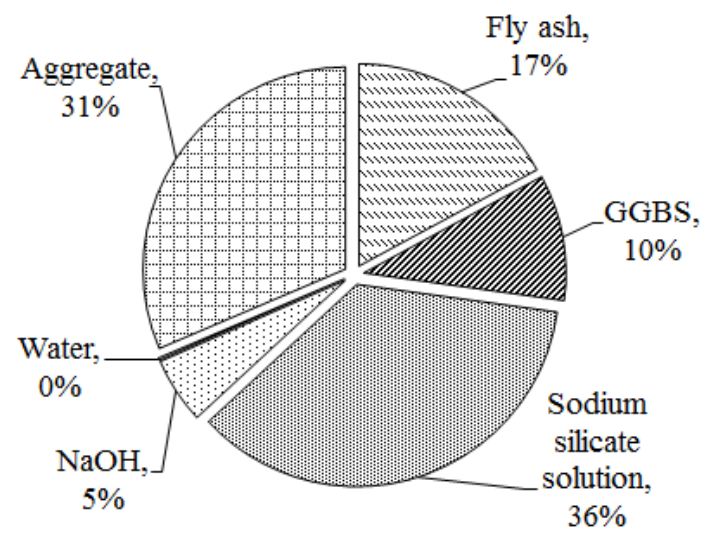

(c) AAC - 50 MPa concrete

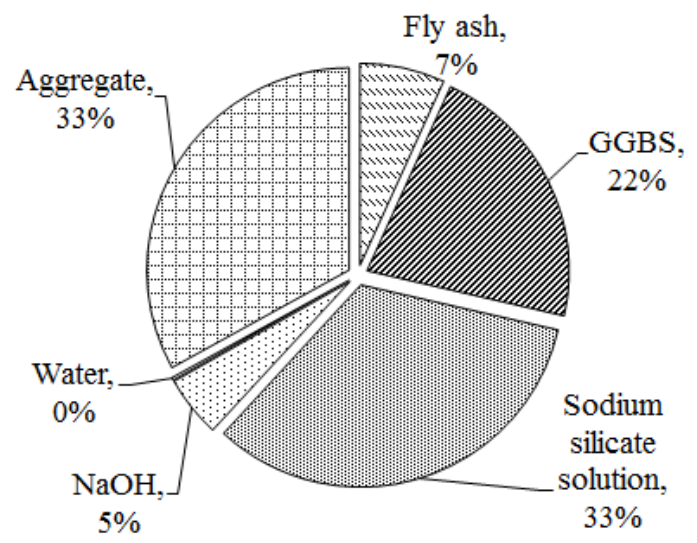

(e) AAC - 70 MPa concrete

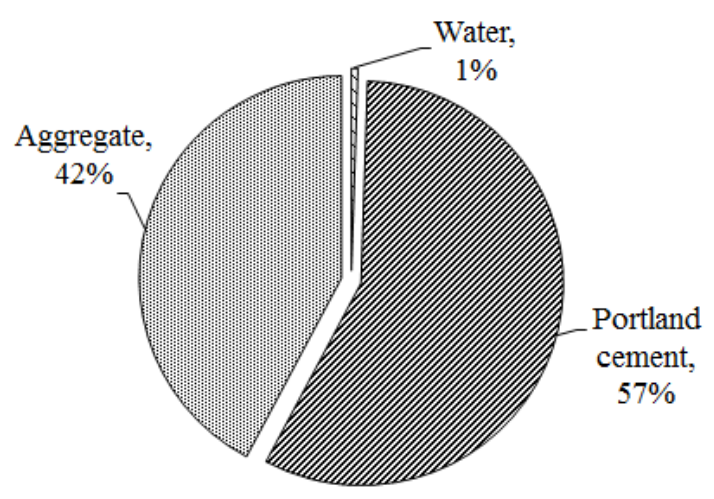

(b) PC - $35 \mathrm{MPa}$ concrete

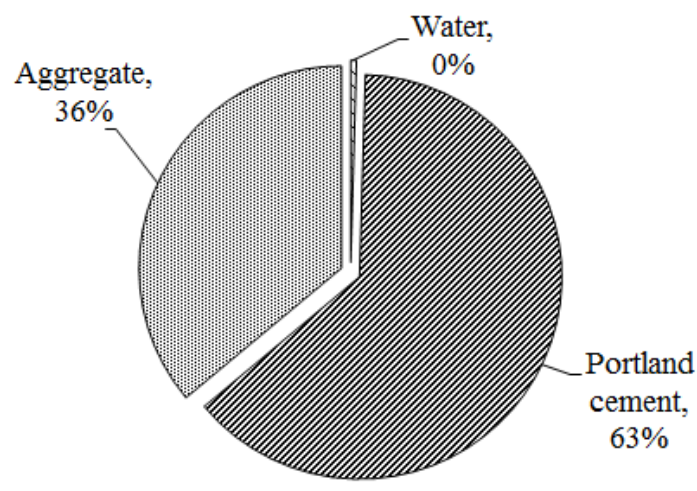

(d) PC - 50 MPa concrete

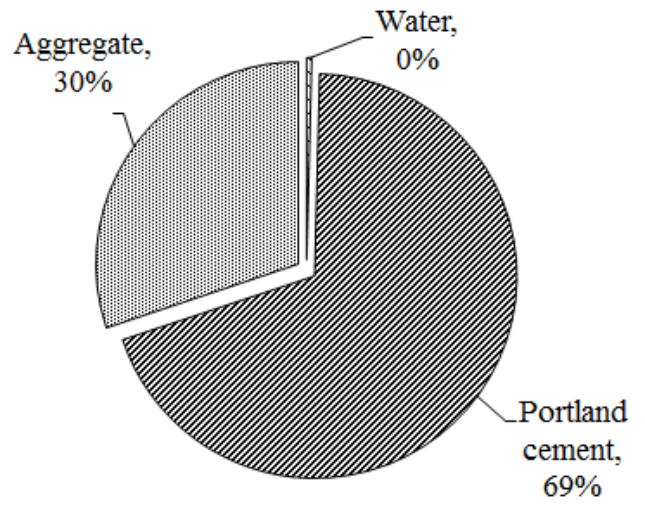

(f) PC - $70 \mathrm{MPa}$ concrete

Figure 10. Relative contribution of constituent materials to the cost $1 \mathrm{~m}^{3}$ of concrete.

Sodium silicate solution and Portland cement were the most costly constituents for AAC and PC concretes respectively. Therefore, a sensitivity analysis was carried out by varying the price of Portland cement and sodium silicate. Price of sodium silicate solution was varied from 125 to $500 \mathrm{f} / \mathrm{t}$, and Portland cement price from 70 to $110 £ / t$. Results are shown in Figure 11. These price ranges were considered realistic for what is 
currently commercially available, i.e. other options such as waterglass from processed by-products, as recently proposed by some authors [31 - 33], has not been considered. Alternative sources of sodium silicate, or processes to produce it, may reduce the cost and the carbon footprint of AAC in the near future.

The following were the trends:

- The higher the compressive strength of Portland cement concrete, the higher its cost is. The relationship is linear.

- The cost of AAC of different strength classes is not significantly different. The binder content does not vary and therefore the quantities of activators are the same.

- The Portland cement price affects high strength PC concrete considerably, as it is about $70 \%$ of the total cost.

- PC-35 concrete is generally less expensive than AAC-35. Cost per cubic metre can be comparable in the case of Portland cement price being high at $110 £ / t$ and sodium silicate solution being lower than $240 £ / \mathrm{t}$.

- In the case of silicate solution price of about 200£/t, AAC-70 unit cost is comparable to PC unit cost even for low price of Portland cement of $70 £ / t$. When Portland cement is priced at $90 £ / t$, AAC-70 can be commercially viable for a silicate solution price of $300 £ / t$.

- In case of a very low cost of silicate solution (i.e. in the range of $125 \mathrm{f} / \mathrm{t}$ ) AAC concrete with compressive strength equal to or higher than $50 \mathrm{MPa}$ can be cheaper than the PC equivalent, even in the case of cement having the current price of $70 £ / t$.

The above are in agreement with what has been reported in the literature, i.e. AAC cost, compared to that of PC, may not be prohibitive where high performance concrete is required and specified [34]. 


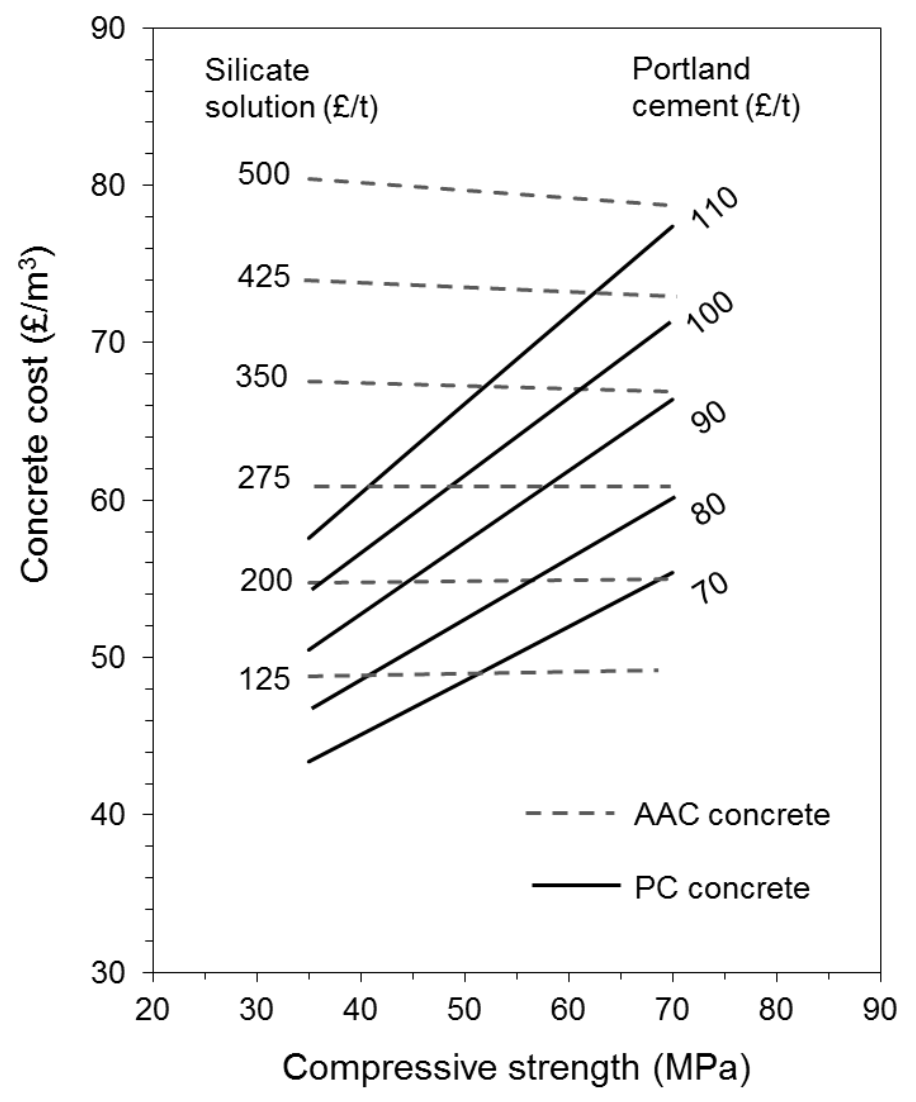

Figure 11. Cost comparison for $1 \mathrm{~m}^{3}$ of concrete.

\section{Conclusions}

Concretes produced with fly ash and GGBS have been investigated to determine the effects of paste volume, w/s ratio and binder blend (fly ash/GGBS) on fresh and hardened properties of concrete. Main results were:

- $\quad$ Paste volume in the range 30\% - 33\% did not influence the compressive strength, but had an important effect on the consistency of the mixes.

- W/s ratio influenced the compressive strength, although this effect was reduced with increasing GGBS content. W/s ratio has significant effects on the setting behaviour. Higher w/s ratio led to longer initial and final setting times.

- Increasing GGBS content in the binder blend resulted in an increase of the compressive strength. Increasing GGBS contents resulted also in shorter setting times.

A step-by-step mix design procedure, starting from required compressive strength, initial setting time and consistency class, has been developed to determine the mix proportions of constituents for a trial mix. The procedure was used to determine the mix proportions for normal, medium and high strength concretes, and 
experimental results validated it. However, the proposed method has its limitation as is based on (a) a specific alkali activator chemical composition and dosage, and (b) one combination of coarse and fine aggregate of certain shape, texture and grading. Further development of the procedure will consider more material parameters.

A cost analysis was carried out for comparing cost between equivalent AAC and PC concretes. The cost analysis indicated that normal strength PC concrete will be less expensive than AAC with current prices. A higher price for PC and a lower price for sodium silicate solution may change this. AAC may be economically more favourable for medium to high strength applications, since the cost per cubic metre was found to be comparable to that of PC-based concrete. Lowering the cost of AAC is necessary for it to become commercially a viable alternative to $\mathrm{PC}$ concrete. Cost may be reduced by identifying alternative alkali activators or processes to produce and sell them at a lower price.

\section{Acknowledgements}

This research was carried out in the framework of the SUS-CON "Sustainable, Innovative and Energy-Efficient Concrete, based on the Integration of All-Waste Materials" project, which has received funding from the European Union Seventh Framework Programme (FP7/2007-2013) under Grant Agreement No. 285463 (Call FP7-2011-NMP ENV-ENERGY-ICT-EeB). Authors also would like to acknowledge the Government of the Sultanate of Oman represented in the Ministry of Manpower, for sponsoring the PhD study of Dr Ali Rafeet.

\section{References}

[1] Provis, J. (2014). Introduction and scope. In Alkali Activated Materials: State of the Art Report, RILEM TC 224-AAM, J. L. Provis and J. S. J. van Deventer (Eds.) Springer, pp 1-9.

[2] Duxson, P., Provis, J. L., Lukey, G. C., \& Van Deventer, J. S. (2007). The role of inorganic polymer technology in the development of 'green concrete'. Cement and Concrete Research, 37(12), 1590-1597.

[3] Van Deventer, J. S. J., Feng, D., Duxson, P. (2010). Patent no. US7691198 B2.

[4] Kakebeeke, P. I. J., Keulen, A. (2013). Patent no. WO2013176545 A1.

[5] Joseph, B., \& Mathew, G. (2012). Influence of aggregate content on the behavior of fly ash based geopolymer concrete. Scientia Iranica, 19(5), 1188-1194. doi:10.1016/j.scient.2012.07.006

[6] Olivia, M., \& Nikraz, H. R. (2011). Strength and water penetrability of fly ash geopolymer concrete. $A R P N$ Journal of Engineering and Applied Sciences, 6(7), 70-78. 
[7] Sayyad, A. S., \& Patankar, S. V. (2013). Effect of steel fibres and low calcium fly ash on mechanical and elastic properties of geopolymer concrete composites. Indian Journal of Materials Science, 1-8. doi: $10.1155 / 2013 / 357563$

[8] Sofi, M., Van Deventer, J. S. J., Mendis, P. A., \& Lukey, G. C. (2007). Engineering properties of inorganic polymer concretes (IPCs). Cement and Concrete Research, 37(2), 251-257. doi:10.1016/j.cemconres.2006.10.008

[9] Wongpa, J., Kiattikomol, K., Jaturapitakkul, C., \& Chindaprasirt, P. (2010). Compressive strength, modulus of elasticity, and water permeability of inorganic polymer concrete. Materials \& Design, 31(10), 4748-4754. doi:10.1016/j.matdes.2010.05.012

[10] Hardjito, D. and Rangan, B. V. (2005). Development and properties of low-calcium fly ash-based geopolymer concrete. Research Report GC-1, Faculty of Engineering, Curtin University of Technology.

[11] Hardjito, D., Wallah, S. E., Sumajouw, D. M., \& Rangan, B. V. (2004). Factors influencing the compressive strength of fly ash-based geopolymer concrete. Civil Engineering Dimension, 6(2), 88-93.

[12] Rangan, B., Sumajouw, D., Wallah, S., \& Hardjito, D. (2006). Reinforced low-calcium fly ash-based geopolymer concrete beams and columns. $31^{\text {st }}$ Conference on Our World in Concrete \& Structures: 16 - 17 August 2006, Singapore

[13] Wallah, S. E., \& Rangan, B. V. (2006). Low-calcium fly ash-based geopolymer concrete: long-term properties. Research Report GC-2, Faculty of Engineering, Curtin University of Technology.

[14] Yost, J. R., Radlińska, A., Ernst, S., \& Salera, M. (2013). Structural behavior of alkali activated fly ash concrete. Part 1: mixture design, material properties and sample fabrication. Materials and Structures, 46(3), 435-447. doi:10.1617/s11527-012-9919-х

[15] Junaid, M. T., Kayali, O., Khennane, A., \& Black, J. (2015). A mix design procedure for low calcium alkali activated fly ash-based concretes. Construction and Building Materials, 79, 301-310. doi:10.1016/j.conbuildmat.2015.01.048

[16] Nath, P., \& Sarker, P. K. (2014). Effect of GGBFS on setting, workability and early strength properties of fly ash geopolymer concrete cured in ambient condition. Construction and Building Materials, 66, 163171. doi:10.1016/j.conbuildmat.2014.05.080

[17] Puertas, F., Palacios, M., \& Provis, J. L. (2014). Admixtures. In Alkali Activated Materials: State of the Art Report, RILEM TC 224-AAM, J. L. Provis and J. S. J. van Deventer (Eds.) Springer, pp 145-156. doi:10.1007/978-94-007-7672-2 
[18] Bernal, S. A., de Gutiérrez, R. M., Pedraza, A. L., Provis, J. L., Rodriguez, E. D., \& Delvasto, S. (2011). Effect of binder content on the performance of alkali-activated slag concretes. Cement and Concrete Research, 41(1), 1-8. doi:10.1016/j.cemconres.2010.08.017

[19] Hung, C. C., Chang, J. J. (2013). The influence of mixture variables for the alkali-activated slag concrete on the properties of concrete. Journal of Marine Science and Technology, 21(3), 229-237. doi: 10.6119/JMST-012-0109-4.

[20] Deb, P. S., Nath, P., \& Sarker, P. K. (2014). The effects of ground granulated blast-furnace slag blending with fly ash and activator content on the workability and strength properties of geopolymer concrete cured at ambient temperature. Materials \& Design, 62, 32-39. doi:10.1016/j.matdes.2014.05.001

[21] Lee, N. K., \& Lee, H. K. (2013). Setting and mechanical properties of alkali-activated fly ash/slag concrete manufactured at room temperature. Construction and Building Materials, 47, 1201-1209. doi:10.1016/j.conbuildmat.2013.05.107

[22] Xin, L., Jin-yu, X., Weimin, L., \& Erlei, B. (2014). Effect of alkali-activator types on the dynamic compressive deformation behavior of geopolymer concrete. Materials Letters, 124, 310-312. doi:10.1016/j.matlet.2014.03.102

[23] Soutsos, M., Boyle, A., Vinai, R., Hadjierakleous, A., Barnett, S. (2016). Factors influencing the compressive strength of fly ash based geopolymers. Construction and Building Materials, 110, 355-368, http://dx.doi.org/10.1016/j.conbuildmat.2015.11.045.

[24] BS 1881-116 (1983). Testing concrete. Part 116: Method for determination of compressive strength of concrete cubes. London: British Standards Institution.

[25] ASTM C403 / C403M-08 (2008). Standard Test Method for Time of Setting of Concrete Mixtures by Penetration Resistance. ASTM International, West Conshohocken, PA.

[26] BS EN 206:2013 (2013). Concrete - Specification, performance, production and conformity. London: British Standards Institution.

[27] Shi, C., Day, R.L. (1996). Some factors affecting early hydration of alkali-slag cements. Cement and Concrete Research, 26(3), 439-447. doi:10.1016/S0008-8846(96)85031-9

[28] Zhang, Z., \& Wang, H. (2014). Analysing the relation between pore structure and permeability of alkaliactivated concrete binders. Handbook of Alkali-Activated Cements, Mortars and Concretes, 235.

[29] Marsh, B. K., Teychenne, D. C., Franklin, R. E., \& Erntroy, H. C. (1997). Design of normal concrete mixes. $2^{\text {nd }}$ edition, Building Research Establishment, Construction Research Communications Ltd, UK. 
[30] Provis, J. L., Palomo, A., Shi, C. (2015). Advances in understanding alkali-activated materials. Cement and Concrete Research, 78, 110-125. doi:10.1016/j.cemconres.2015.04.013

[31] Puertas, F., \& Torres-Carrasco, M. (2014). Use of glass waste as an activator in the preparation of alkaliactivated slag. Mechanical strength and paste characterisation. Cement and Concrete Research, 57, 95-104.

[32] Bernal, S. A., Rodríguez, E. D., de Gutiérrez, R. M., Provis, J. L., \& Delvasto, S. (2012). Activation of metakaolin/slag blends using alkaline solutions based on chemically modified silica fume and rice husk ash. Waste and Biomass Valorization, 3(1), 99-108.

[33] Živica, V. (2006). Effectiveness of new silica fume alkali activator. Cement and Concrete Composites, $28(1), 21-25$.

[34] Sonafrank, C. (2010). Investigating $21^{\text {st }}$ century cement production in interior Alaska using Alaskan resources. Cold Climate Housing Research Center, Report, 12409. 